\title{
Beneficial Bioelectrochemical Systems for Energy, Water, and Biomass Production
}

Veera Gnaneswar Gude ${ }^{1}$, Bahareh Kokabian ${ }^{1}$ and Venkataramana Gadhamshetty ${ }^{2 *}$

${ }^{1}$ Civil and Environmental Engineering, Mississippi State University, USA

${ }^{2}$ Environmental Engineering, Florida Gulf Coast University, USA

\begin{abstract}
The major insecurities facing the modern world are tied to depleting fuel reserves and rising greenhouse gas emissions. A quest for clean and renewable fuels has invigorated research efforts in both developed and developing countries. Microbial Fuel Cell (MFC) technology has been promoted as an innovative application of microbes for producing sustainable energy from organic waste streams emerging from a variety of waste sources. The latest scientific discoveries in MFC technology provide a framework for multitude of MXC technologies, ranging from Microbial Desalination Cells (MDCs) used in desalination of brackish water; Microbial Electrolysis Cells (MECs) used for production of hydrogen; and microbial solar cells (MSCs) for sequestration of carbon dioxide from atmospheric and anthropogenic sources. The MXCs demonstrate a potential for sustainable water treatment and clean energy production under environmentally benign conditions. This article provides a critical overview of MXCs with a special focus on MDCs.
\end{abstract}

Keywords: Microbial Fuel cells, Desalination, Sustainable Energy, Microbial Desalination Cells, Microbial Solar Cells, Algae

\section{Introduction}

Microbial fuel cells (MFCs) operate in a galvanic mode: they employ microbial catalysts to extract oxidation current from waste organic matter in the anodic half-cell; and use chemical catalysts in the cathodic half-cell to consume electrons in the presence of protons and terminal electron acceptor. The anode can be designed for treatment of municipal waste streams, and high-strength organic wastes emerging from cattle farms, breweries, landfills, chocolate factories, and food processors[1-6] while the reducing conditions in the cathodic halfcell provide a legitimate route for treating oxidized contaminants (e.g. nitrates and chromium)in water bodies [7]. The cathodes have been demonstrated for treatment of perchlorate [8], uranium (UVI) [9], and chlorinated compounds (e.g. chloro ethene, 2-chlorophenol, and pentachlorophenol) [10,11]. MXCs refer to new bioelectrochemical systems that share the principles of MFCs, with a slight variation in the anode and/or cathode configuration. For instance, Microbial desalination cell (MDC) is a variant of MFC which includes an additional middle chamber for sustainable energy production (from organic wastes) and water desalination. The MDCs can be designed for treatment of organic waste and simultaneous desalination of saltwater [12].

Other versions of MXCs include microbial electrolysis cell (MECs), microbial reverse-electrodialysis cell (MRC), and microbial solar cell (MSC). The MRCs produce electric power from entropic energy based on the salinity difference between seawater and river water [13]; the MECs deliver hydrogen, or methane from organic wastes [14,15]; MSCs use photosynthetic bacteria to convert solar energy into electricity [16], all with the aid of tiny microbes and sustainable waste matter.

Modest amount of literature exists in the domains of microbial fuel cell research. Palmore and White sides summarized biological fuel cell concepts and performance up to 1992. Logan provided detailed review on the basic operation, materials, and architecture of MFC technology upto 2007 [17]. Details on the scale-up prospects of MFC technology have been recently reported in the scientific literature [18]. Torres et al. reported a perspective on extracellular electron transfer by anode- respiring bacteria [19]. Venkatamohan et al. have investigated the performance of MFCs with non-catalyzed MFCs [20]. Rabaey and Verstraete discussed the aspects of electron transfer, metabolism and energy losses in MFCs [21]. A state of the art review on MFC technology for wastewater treatment has been provided by $\mathrm{Du}$ et al. [22]. He et al. [7] provided comprehensive details on the experimental progress of biocathodes in microbial fuel cells (MFCs). Rabaey \& Verstraete [21] described the mechanisms of electron transfer in the anode, while Rishman-Yazdi et al. [23] summarized the factors relevant to cathodic limitations in MFCs. Pham et al. provided a critical comparison of the conventional AD technology and the MFC technology [24]. Schroder et al. discussed the electron transfer processes in MFCs $[25,26]$. Kim and Logan published a first review article that describes the research progress of microbial desalination technology [12]. This article does not replicate these valuable contributions, and instead, updates recent advances on emerging MXCs that build upon the R\&D framework of MFC technology. This article focuses on the development of microbial desalination cell and microbial solar cell technology in recent years.

\section{A Brief History on Mxcs}

During $18^{\text {th }}$ century, Luigi Galvani provided the first experimental evidence on bioelectricity by recording the electric response obtained from connecting frog legs to a metallic conductor [27]. In 1911, Michael C. Potter demonstrated the electric current production through microbial oxidation of non-electrolytes (e.g organic compounds) [28]. In 1931, Barnett Cohen reconfirmed Potter's results by producing $0.2 \mathrm{~mA}$ current by poising a half cell at $+0.5 \mathrm{~V}$ using a potentiostat

*Corresponding author: Venkataramana Gadhamshetty, Environmenta Engineering, Florida Gulf Coast University, USA, Tel: 1239590 7647; Fax: 1239 590 7801; E-mail: vgadhamshetty@fgcu.edu

Received April 01, 2013; Accepted July 23, 2013; Published July 26, 2013

Citation: Gude VG, Kokabian B, Gadhamshetty V (2013) Beneficial Bioelectrochemical Systems for Energy, Water, and Biomass Production. J Microb Biochem Technol S6: 005. doi:10.4172/1948-5948.S6-005

Copyright: $\odot 2013$ Gude VG, et al. This is an open-access article distributed under the terms of the Creative Commons Attribution License, which permits unrestricted use, distribution, and reproduction in any medium, provided the original author and source are credited 
[29]. The MFC technology became popular in 1960's when NASA proposed a novel idea to use MFCs for producing electricity from human waste during space flights [30]. The interest in MFC research was revived in 1980s when $\mathrm{H}$. Peter Bennetto demonstrated the use of artificial mediators to enhance electric power in MFCs [31]. Past decade has attracted the scientific community to MFC research due to a spectacular discovery on the extracellular electron transport (EET) mechanism in microbes that allows them to use insoluble solid surfaces as a terminal electron acceptor; in other words, microbes can transport electrons outside their cell wall in order to breathe and survive in anaerobic environments that lack fermentable substrates (e.g. glucose) and conventional, terminal electron acceptors (e.g. dissolved oxygen and nitrate). [32,33]. The details on EET mechanisms and their influence on MFC performance are well described in the literature $[34,35]$. Another important discovery in the MFC research which led to the birth of microbial desalination cells (MDCs) is the ability of MFCs to facilitate ionic transport when an additional chamber of salt water is introduced between the anode and cathode chambers to achieve removal of salts [12]. The fundamental principles of operation and process developments of MDCs are discussed in the later sections.

\section{Microbial Desalination Cell (Mdc)}

The MDCs share the principle of bioelectrochemical reactions in MFCs. The MDC couples ionic current in the electrolyte with electric current at the electrodes, via bioelectrochemical oxidation of organic matter at the anode, and electrochemical reduction at the cathode respectively. The discussion on the anode in following subsections is applicable to both MFCs and MDCs.

\section{Working Principle}

A laboratory model for a typical MDC reactor is comprised of anode, desalting chamber, and the cathode (Figure 1). In the anode, the microbes break organic matter into protons, electrons, and other byproducts. The electrons from the metabolic oxidation of organic matter, are transferred to the solid anode, and permanently discharged via current collectors into the cathode. The electrons disposed by the microbes in the anode are extracted as DC current by inserting an external load in the electric circuit. The electron acceptors (e.g. oxygen) in the cathode serve as a permanent sink for electric current and ionic current.

A desalination cell is sandwiched between the anode and cathode chambers of an MFC, and the anolyte and catholyte are isolated with anion exchange membrane (AEM) and cation exchange membrane (CEM) respectively (Figure 1). The desalination is achieved by the transfer of negative and positive ions across AEM and CEM respectively. In order to preserve electroneutrality condition due to discharge of electric current from the bioelectrochemical oxidation of organic matter in the anode, the negatively charged ions from the desalination cell (e.g. $\mathrm{Cl}^{-}, \mathrm{NO}_{3}{ }^{-}$and $\mathrm{SO}_{4}{ }^{2-}$ ) migrate to the anode. Similarly, in the cathode, the terminal electron acceptors (e.g. oxygen) receive electrons to form reduced compounds, and in turn, positively charged ions from the desalination chamber (e.g. $\mathrm{Na}^{+}, \mathrm{Ca}^{2+}$ and $\mathrm{Mg}^{2+}$ ) pass through the cation exchange membrane to the cathode chamber [36]. In other words, the transport of cations and anions are restricted in the anode and cathode compartments respectively. The working principles and operational details have been described in the recent literature [12]. The overall effect of bio-electro-chemical processes in MDCs results in simultaneous power generation and water desalination [36].

The recent versions of MDCs include three chamber MDCs,

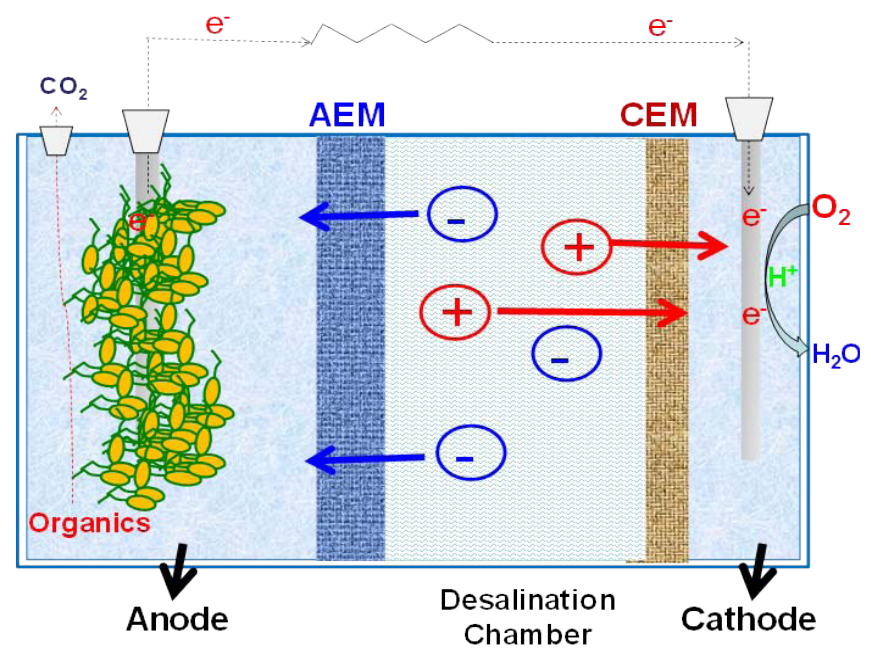

Figure 1: A schematic of microbial desalination cell [11]

microbial desalination-electrolysis cells (MECs), bipolar MDC, and osmotic MDCs (MODCs). The desalting capacity of MDCs can be increased by stacking more than one membrane pair between anode and cathode. The body of scientific literature includes detailed reports on the desalination capacity and efficiency of both unit MDCs and stacked MDCs [37-44]. Upflow MDC reactors have been recently developed to demonstrate the feasibility of microbial desalination at liter-scale flow rate capacity, and promote its potential for large scale application $[45,46]$.

\section{Physiological Conditions (Anode)}

The role of microbes in the anode is to retrieve the chemical energy in a non-electrolyte (e.g. glucose) to a form suitable for electrochemical oxidation and then into electrical energy [47]. The microbes convert biochemical energy into Adenosine Triphosphate (ATP) by cascading a series of redox reactions, and finally transmitting electrons from organic substrates (e.g. glucose) to a solid anode. The electricityproducing microbes in MFCs are coined as anode-respiring bacteria (ARB) as they use solid anode as the terminal electron acceptor [48]. The growth rate of ARBs depends on the difference between redox potential of the electron donor, and the actual potential of the anode. At the same time, the lower anode potential (negative potential) provides a high voltage gradient, and therefore maximizes the possibility of high current densities in MDCs. Amongst myriad of factors, the type and concentration of electron donor, electrical properties of MDC, the choice of electrode and membranes, and physiological conditions (e.g. $\mathrm{pH}$, temperature, concentrations of micronutrients and vitamins, and mixing conditions), all exert a strong impact on the anode potential. [26].

Anode Potential: Theoretically, the higher (i.e. positive) anode potential is expected to yield higher energy gain for the growth of anode-respiring bacteria. However, literature indicates that lower anode potentials (i.e. negative potentials) are conducive to the growth of ARB biofilm on the anode surface. Lee et al. [48] conducted comprehensive experiments to investigate the effect of anode potential on the evolutionary pattern of the biofilm community on the anode surface, and its subsequent effect on the electrical performance of MFCs. The experiment used waste water activated sludge as inoculum, acetate as the electron donor, and the hydrodynamic conditions were 
controlled in continuous-flow reactor. A potentiostat was used to set the anode potential of four MFCs at four different values $(0.15,-0.09$, +0.02 , and $+0.37 \mathrm{~V}$ vs SHE). They discovered that the MFC set at the lowest anode potential (-0.09) demonstrated a faster biofilm growth and higher current densities $\left(10.3 \mathrm{~A} / \mathrm{m}^{2}\right)$ [48]. A potentiostat can be used to maintain the anode potential at a precise value that delivers optimal growth of ARBs in MFCs. In absence of potentiostat, the anode potential is determined by the composition of microbial communities and physiological conditions (e.g. $\mathrm{pH}$, temperature, electron donor, and electrochemical losses) [48].

\section{Electron Acceptors and Biocathodes}

Chemical oxidants such as ferricyanide are used as a laboratory models for electron acceptors in the cathode of MDCs. Ferricyanide offer high cathodic potential and faster reduction kinetics in MDC experiments. The use of these chemicals is limited to laboratory use due to their toxic characteristics and high costs. Oxygen has been recognized as a practical terminal electron acceptor (TEA) due to its high reduction potential, and in addition, oxygen can be obtained from air. The cathodes using oxygen as TEA is popularly termed as air cathodes. The major limitation to the air cathodes is that they suffer with a disadvantage of slower redox kinetics under ambient conditions; these cathodes therefore require expensive catalyst materials (e.g. platinum) for minimizing activation over potential associated with oxygen reduction. Another disadvantage is related to the high energy requirements associated with mechanical equipments used to maintain optimal dissolved oxygen concentrations in the air cathodes. Logan et al. [18] offered the following innovative approaches to minimize some of the disadvantages with air cathodesin MFCs, and these strategies are applicable to microbial desalination cells as well: i) the aeration requirements can be minimized by exposing air cathodes in MDCs to atmosphere [18]; ii) aeration costs can also be reduced by using passive methods to achieve oxygen transfer in the cathodes [35,49,50]; iii) ultra-high surface area carbon substrates (e.g. activated carbon) in the air cathodes may reduce the need for platinum catalysts and still acceptable levels of oxygen reduction in the absence of platinum catalysts [18].

Biocathodes represents an innovative approach to produce sustainable cathodes using microbes as catalysts to facilitate electrochemical reduction on the cathode surface. The biocathodes eliminate the need for expensive chemical catalysts, lower construction and operational costs, and offer flexibility in producing valuable commodities [7,51-55].

The biocathode requires optimal physiological conditions that promote microbial growth on the cathode surface. Unlike ARB in the anode, the microbes in the biocathode should have ability to receive electrons from the cathode surface (i.e. electrotrophic). The growth of biofilms on the cathode may be achieved with special techniques such as electrical inversion of electrodes. For instance, hydrogen-evolving biocathodes can be obtained with an electrical inversion of organics-oxidizing bioanode using following procedure: i) obtain a typical MFC with organics-oxidizing bioanode and a ferricyanide-reducing chemical cathode, and ii) switch the bioanode to a hydrogen-producing biocathode, and simultaneously convert ferricyanide-cathode to ferrocyanide-anode [56]. Similarly, Pisciotta et al. [57] used an electrode inversion method to obtain biocathode capable of $\mathrm{CO}_{2}$ fixation and simultaneous hydrogen production. Few scientific studies have confirmed that the biofilm-laden cathode can be conditioned under oxic environment and then switched to a current- generating anode [58-60]. This indicates that both exoelectrogenic and electrotrophic microorganisms can be maintained in the electrode biofilms when the cathode is switched from oxic to anoxic conditions. While this approach was successful for producing biocathodes for oxygen reduction (aerobic biocathodes), it was not clear if bioanodes would necessarily contain electrotrophic microorganisms that function under anoxic conditions [57].

\section{Electrode Materials}

The type of electrode plays a critical role in determining the electrical performance of microbial desalination cells. The basic requirements for the electrode materials include high electrical conductivity, large surface area with accessible pores, enhanced mass transfer characteristics, chemical stability, mechanical strength, biocompatibility, low cost, and scalability. The currently used carbon electrodes (e.g. graphite felt, graphite rod, graphite foam, vitreous carbon and carbon cloth) were originally designed for chemical fuel cells, and may not be a best choice for MFC applications. These materials suffer from disadvantage of a low specific surface area $\left(<1 \mathrm{~m}^{2} / \mathrm{g}\right)$. A graphite brush was used to develop novel anode architecture that provides high surface area $(18000$ $\mathrm{m}^{2}$ of electrode surface per $\mathrm{m}^{3}$ of brush volume), high porosity (95\%), and efficient current collection [18]. The nanomaterials may provide opportunities to obtain efficient electrodes in MDC applications. The large surface area and high electrical conductivity may enhance bioelectrochemical kinetics of the surface reactions on the electrodes in MFCs. Nanomaterials such as carbon nanotube and graphene sheets can be assembled into self-standing, self-supporting macroscopic paperlike electrode materials that are scalable for practical applications [61]. Such nanocomposites are endowed with high electrical conductivity $(\sim 10 \mathrm{~S} / \mathrm{cm})$ and exceptional specific surface areas $\left(\sim 1000 \mathrm{~m}^{2} / \mathrm{g}\right)$ [61].

Following CNT nanocomposites have been evaluated as anode materials in MFCs, and can therefore be extended to MDC applications: (a) biological composites, i.e. bacterial cells directly immobilized on non-cytotoxic CNTs, (b) noble-metal based CNT-NCs (e.g. platinum), (c) Natural-polymers based CNT-NCs and (d) conducting-polymers based CNT-NCs. The metal-anchored CNT have also been proven to be improve power generation in MFC applications. The comprehensive details on the application of CNT-based anodes have been provided in the literature [62]. Like CNTs, pristine graphene can be functionalized with covalent and non-covalent groups to obtain nano-composite materials. Zhang and his co-workers described the utility of graphene and graphene oxide nanoribbons as a means to obtain high-performing anodes. Xiao et al. [63] reported the use of crumpled graphene balls in MFC applications. More recently, Krishnamoorthy et al. [64] described the implications of using Nickel/graphene composite as anodes.

The use of metallic electrodes (e.g. stainless steel) has been explored in MFC applications. To name a few, Dumas et al. [65] has indicated the feasibility of stainless steel plate as the anode both the anode and biocathode electrodes in an MFC, and reported power density values of $23 \mathrm{~mW} / \mathrm{m}^{2}$. Similarly, Erable and Bergel [66] evaluated the use of stainless steel grid as anode material. Heijne et al. [67] has demonstrated the use of titanium as the anode material in MFCs. Metal and metal oxidation-coated anodes have also been proposed in microbial fuel cell applications [68]. For instance, graphite modified with $\mathrm{Fe}_{3} \mathrm{O}_{4}$ and nickel $\left(\mathrm{Ni}^{2+}\right)$ possessed nearly 2.2 fold higher kinetic activities compared to plain graphite. A recent study by Xueying et al. [69] reported power density of $996 \mathrm{~mW} / \mathrm{m}^{2}$ using a nickel-coated sponge as the anode in a MFC. 
The type of cathode also influences the performance of MDCs. For instance, it has been reported that the cathode material influences the growth and performance of microbial communities on the surface of biocathode. The electrodes differ in conductivity, surface area and porosity and thereby influence the performance of biocathode in MDCs. These differences affect the adhesion and biofilm growth characteristics of microbial communities on the cathode surface. The precise influence of electrode materials on the composition of microbial communities in the biocathode is an intriguing subject of scientific research. For instance, Sun et al. [51] evaluated four different electrode materials (i.e., granular activated carbon (GAC), granular semicoke (GS), granular graphite (GG) and carbon felt cube (CFC)) on the evolutionary pattern of microbial communities in the biocathodes. Their results demonstrated an influence of electrode materials on the type and composition of microbial species in biofilm communities. The microbes belonging to Bacteriodetes and Proteobacteria were the dominant phyla on all the four materials. Comamonas of Betaproteobacteria have been reported to play a significant role in electron transfer process of biocathodes with GAC, GS and CFC, while Acidovorax played a key role in the GG packed MFC [51].

\section{Design Constraints of MDC Technology}

An optimized reactor design is critical to the success of MDC applications. The rate of current production in MDCs is directly related to the rate of desalination and wastewater treatment. The optimum MDC configuration will ensure simultaneous benefits of wastewater treatment (higher contaminant removal), water desalination (higher salinity removal) and higher power production. Intuitively, it may appear that higher current generation can be made possible with application of low external resistance, however, this was not reported to be true [37]. Similar to MFCs, the power densities in MDCs can be enhanced by reducing electrochemical losses such as activation over potential, ohmic losses, and mass transfer limitations. Optimization ofdesign parameters such as hydraulic flow and salinity difference (between the anode and desalination) can enhance the performance of MDCs. The MDC designs with low inter-electrode-spacing (IES), i.e. distance between the anode and cathode), larger anode surface area/volume $\left(\mathrm{m}^{2} / \mathrm{m}^{3}\right)$; efficient chemical catalysts (e.g. platinum) have been reported to minimize electrochemical losses in the cathode. The state-of-art laboratory MDCs demonstrates power densities as high as $\sim 31 \mathrm{~W} / \mathrm{m}^{3}$ (power densities normalized to anode chamber working volume) with oxygen reduction reaction [46] and a current density of $\sim 8.5 \mathrm{~A} / \mathrm{m}^{2}$ (current density normalized to cross-sectional surface area of anode exchange membrane) [70]. Table 1 summarizes the electrical performance of different microbial desalination cells (MDCs) varying in electrode-type, membrane materials, and reactor configurations.

In a recent publication, Kim and Logan indicated a need for technological innovations to improve the prospects for MDCs technology [12]. The $\mathrm{pH}$ fluctuations in the anode and cathode have been reported to be an operational issue with MDCs. The abrupt $\mathrm{pH}$ decrease in the anode hinders the metabolic activity of the anoderespiring bacteria (ARB). In a similar manner, the $\mathrm{pH}$ increases rapidly in the cathode chamber. Therefore, MDCs require extensive buffering capacity to maintain the physiological conditions of microbes in a neutral range. Two major approaches have been recommended for mitigating $\mathrm{pH}$ fluctuations in the MDC systems. The first approach involves a constant recirculation of the electrolyte between anode and cathode (or mixing the high $\mathrm{pH}$ catholyte with the incoming anolyte solution) and the second approach recommends daily replacement of the anolyte in MDC [37]. The first approach has been observed to reduce desalination efficiency, while the second approach results in a significant consumption of buffering chemicals, micronutrients, vitamins, and trace nutrients. Both the approaches may not be viable in large scale MDC applications.

The MDCs can be stacked in a series to increase the desalination capacity. The first stack of MDCs was tested by Chen et al. [37] using two cell pairs between the anode and air cathode; however, the desalination efficiency was reported to below which was likely due to internal resistance caused by thick desalination chamber $(\sim 1 \mathrm{~cm})$. Kim and Logan suggested three strategies to alleviate problems associated with stacked MDCs (SMDCs): i) use a thin stack to minimize the ohmic resistance, ii) use seawater as the catholyte and eliminate the need for chemical buffers and iii) incorporate a novel water flow scheme through the stack. A new flow design was used in which the concentrate and dilute flow serially into every desalination cell in the stack which resulted in higher desalination capacity and efficiency [43].

A challenge with stacked MDCs is related to the transfer of the dilute water into the concentrate due to osmosis. This osmotic water loss can be minimized by reducing the hydraulic residence time or decreasing the cross sectional area of the membrane. The effective approach to increase the desalination capacity is to link seawater flows to multiple MDCs in a series, instead of increasing the number of stacks in one unit of MDC [43].

Microbial inhibition due to the migration of chloride ions to the anode chamber is another major issue in MDCs. Further, the use of phosphate buffers in the anode can result in migration of phosphate to the desalination cell that can combine with $\mathrm{Mg}^{2+}$ and $\mathrm{Ca}^{2+}$ to form heavy deposits [70].

Microbial Capacitive desalination cell (MCDC) was proposed by Forrestal et al. [71] to address the salt migration and $\mathrm{pH}$ fluctuation problems and improve the efficiency of capacitive deionization. The anode and cathode chambers of the MCDC were separated from the middle desalination chamber by two specially designed membrane assemblies, which consisted of cation exchange membranes and layers of activated carbon cloth (ACC). The two cation exchange membrane assemblies allowed the free transfer of protons across the system and prevented significant $\mathrm{pH}$ changes observed in traditional MDCs. Ion exchange resins can be introduced into MDCs to avoid undesirable migration of counter ions to the anode and cathode chambers [72]. However, this results in additional electrical impedance in MDC systems and increases expenditure due to use of expensive resin material.

To increase the water transport in MDCs, a new concept called osmotic MDC (MODC) was introduced [44]. Forward osmosis (FO) membranes have been used to replace the anode exchange membrane to allow passage of water molecules from the anode chamber to recover water which then was proposed to pass through a reverse osmosis process. Comparing the desalination in closed and open circuit configurations, open configuration demonstrated that the majority of the desalination occurred due to electric generation at low initial concentration of salts. However, in high initial concentration of salt, dilution was the main contributor for desalination. Therefore, MODC offers benefits of high water recovery from wastewater and enhanced conductivity removal during desalination of saline waters. The $\mathrm{pH}$ of the middle chamber has been observed to be lower in the MODC compared to MDCs. This is due to the fact that the water flux (from 
Citation: Gude VG, Kokabian B, Gadhamshetty V (2013) Beneficial Bioelectrochemical Systems for Energy, Water, and Biomass Production. J Microb Biochem Technol S6: 005. doi:10.4172/1948-5948.S6-005

Page 5 of 14

\begin{tabular}{|c|c|c|c|c|c|c|c|c|c|c|c|}
\hline $\begin{array}{l}\text { Anion Ex- } \\
\text { change } \\
\text { Membrane } \\
\text { (Manufac- } \\
\text { turer) }\end{array}$ & $\begin{array}{c}\text { Cation } \\
\text { exchange } \\
\text { membrane } \\
\text { (Manufacturer) }\end{array}$ & Anode & $\begin{array}{l}\text { Cathode } \\
\text { (catalyst) }\end{array}$ & $\begin{array}{c}\text { Anode } \\
\text { (Acetate/ } \\
\text { xy } \\
\text { lose, g/l) }\end{array}$ & $\begin{array}{l}\text { Desalina- } \\
\text { tion } \\
\text { g/l [Media] }\end{array}$ & $\begin{array}{l}\text { Cathode } \\
\text { Medium }\end{array}$ & $\begin{array}{l}\text { Desalina- } \\
\text { tion }\end{array}$ & $\begin{array}{c}\text { COD } \\
\text { removal }\end{array}$ & $\begin{array}{c}\text { Open circuit } \\
\text { voltage }\end{array}$ & $\begin{array}{l}\text { Power } \\
\text { Density }\end{array}$ & Ref. \\
\hline $\begin{array}{c}\text { AnAEM, } \\
\text { DF120, } \\
\text { Tianwei } \\
\text { Membrane }\end{array}$ & $\begin{array}{l}\text { CMI7000, } \\
\text { Membranes } \\
\text { International }\end{array}$ & Carbon felt & $\begin{array}{l}\text { Carbon } \\
\text { felt }\end{array}$ & 1.6 & $5-35$ & Ferricyanide & $(94-88 \%)$ & NA & $700 \mathrm{mV}$ & $2 \mathrm{~W} / \mathrm{m}^{2}$ & 36 \\
\hline $\begin{array}{c}\text { AMI-7001, } \\
\text { Membranes } \\
\text { International } \\
\text { Inc, 2) } \\
\text { R-5500, Solvay } \\
\text { Advanced } \\
\text { Polymers }\end{array}$ & $\begin{array}{l}\text { CMI-7000, } \\
\text { Membranes } \\
\text { International }\end{array}$ & $\begin{array}{l}\text { Ammoniatreated14 } \\
\text { carbon } \\
\text { cloth } \\
\text { (BASF, NJ). }\end{array}$ & $\begin{array}{l}\text { carbon } \\
\text { cloth } \\
\text { (platinum) }\end{array}$ & 1 or 2 & 5-20 (Water) & 50 mM PBS & $43-67 \%$ & $77 \%$ & NA & $\begin{array}{c}480 \\
\mathrm{~mW} / \mathrm{m}^{2}\end{array}$ & 40 \\
\hline $\begin{array}{c}\text { AMI-7001, } \\
\text { Membrane } \\
\text { International, } \\
\text { Inc }\end{array}$ & $\begin{array}{l}\text { CMI-7000, } \\
\text { Membrane } \\
\text { International } \\
\text { Inc }\end{array}$ & $\begin{array}{l}\text { Graphite } \\
\text { granul }\end{array}$ & $\begin{array}{l}\text { Carbon } \\
\text { cloth+Pt }\end{array}$ & 4 & $\begin{array}{c}30 \mathrm{~g} / \mathrm{l} \\
\text { (Water) }\end{array}$ & & $99 \%$ & NA & & $30.8 \mathrm{~W} / \mathrm{m}^{3}$ & 46 \\
\hline $\begin{array}{l}\text { AMI-7001, } \\
\text { Membrane } \\
\text { International } \\
\text { Inc }\end{array}$ & $\begin{array}{l}\text { CMI-7000, } \\
\text { Membrane } \\
\text { International } \\
\text { Inc }\end{array}$ & $\begin{array}{l}\text { Carbon } \\
\text { brush }\end{array}$ & $\begin{array}{l}\text { Carbon } \\
\text { Cloth+Pt }\end{array}$ & 3 & $\begin{array}{c}35 \mathrm{~g} / \mathrm{l} \\
\text { (artificial sea } \\
\text { water) }\end{array}$ & & $\begin{array}{c}94.3 \% ; 73.8 \\
\%\end{array}$ & $92 \%$ & & $\begin{array}{c}28.9,11.1 \\
\mathrm{~W} / \mathrm{m}^{3}\end{array}$ & 45 \\
\hline $\begin{array}{c}\text { AR204-SZ- } \\
\text { RA-412 }\end{array}$ & $\begin{array}{c}\text { CR67-HMR- } \\
412\end{array}$ & $\begin{array}{l}\text { Heat } \\
\text { treated } \\
\text { graphite } \\
\text { brush }\end{array}$ & $\begin{array}{l}\text { carbon } \\
\text { cloth(PTF } \\
\text { E) }\end{array}$ & $2 \mathrm{~g} / \mathrm{l}$ & $\begin{array}{c}50 \mathrm{mM}(\mathrm{Na}+ \\
50 \mathrm{mM} \\
\mathrm{Mg}^{2+}, \text { and } 50 \\
\mathrm{mM} \mathrm{Ca}^{2+}, 50 \\
\mathrm{mM} \mathrm{Cl}^{-}, 50 \\
\left.\mathrm{mM} \mathrm{Br}^{-}\right) \\
50 \mathrm{mM} \\
\mathrm{SO}_{4} 2-\end{array}$ & $\begin{array}{l}100 \mathrm{mM} \\
\mathrm{PBS}\end{array}$ & $13 \%-29 \%$ & $25 \%$ & & $660 \mathrm{~mA} / \mathrm{m}^{2}$ & 73 \\
\hline AMI 7001 & CMI 7000 & $\begin{array}{l}\text { heated } \\
\text { graphite }\end{array}$ & $\begin{array}{l}\text { carbon } \\
\text { cloth }\end{array}$ & WW & 5.85 (Water) & Ferricyanide & $66 \%$ & & $\begin{array}{c}C C V=700 \\
m V \\
R=1000 \Omega\end{array}$ & $8.01 \mathrm{~W} / \mathrm{m}^{3}$ & 42 \\
\hline $\begin{array}{l}\text { DF120, } \\
\text { Tianwei }\end{array}$ & $\begin{array}{c}\text { CMI7000, } \\
\text { Membrane } \\
\text { International) }\end{array}$ & $\begin{array}{l}\text { carbon } \\
\text { graphite } \\
\text { fiber } \\
\text { brushes }\end{array}$ & $\begin{array}{l}\text { carbon } \\
\text { cloth }\end{array}$ & $\begin{array}{l}\text { carbon } \\
\text { cloth }\end{array}$ & 20 (Water) & $\begin{array}{c}25 \mathrm{mM} \text { or } 50 \\
\mathrm{mM} \\
\mathrm{PBS}\end{array}$ & $39 \%-25 \%$ & & $\begin{array}{c}\mathrm{CCV}=500 \\
\mathrm{mV}, \mathrm{R}=1000 \\
\Omega\end{array}$ & $\begin{array}{c}931 \\
\mathrm{~mW} / \mathrm{m}^{2}\end{array}$ & 41 \\
\hline $\begin{array}{l}\text { AMV, Asahi } \\
\text { glass }\end{array}$ & $\begin{array}{l}\text { CMV , Asahi } \\
\text { glass }\end{array}$ & $\begin{array}{l}\text { graphite } \\
\text { fiber } \\
\text { granules }\end{array}$ & $\begin{array}{l}\text { platinum } \\
\text { nanopartic } \\
\text { le } \\
\text { catalysts }\end{array}$ & $1 \mathrm{~g} / \mathrm{l}$ & 35 (Water) & $\begin{array}{l}\text { Synthetic } \\
\text { sea } \\
\text { water }\end{array}$ & $98 \%$ & & & $\begin{array}{c}800- \\
1140 \mathrm{~mW} / \\
\mathrm{m}^{2}\end{array}$ & 43 \\
\hline $\begin{array}{c}\text { DF120, } \\
\text { Tianwei } \\
\text { Membrane }\end{array}$ & $\begin{array}{l}\text { CMI 7000, } \\
\text { Membranes } \\
\text { International }\end{array}$ & carbon felt & $\begin{array}{c}\text { carbon } \\
\text { cloth (platinum) }\end{array}$ & 1.64 & 20 (Water) & PBS & $99 \%$ & & $7.43 \mathrm{~mA}$ & & 37 \\
\hline $\begin{array}{l}\text { AMI-7001S, } \\
\text { Membranes } \\
\text { International }\end{array}$ & $\begin{array}{l}\text { (CMI-7000S, } \\
\text { Membranes } \\
\text { International }\end{array}$ & $\begin{array}{l}\text { Graphite rod } \\
\text { pushed to } \\
\text { carbon felt }\end{array}$ & $\begin{array}{l}\text { Graphite } \\
\text { rod pushed } \\
\text { to carbon } \\
\text { felt }\end{array}$ & 1.6 & 35 (water) & $\begin{array}{c}\text { Aerobic } \\
\text { biocathode }\end{array}$ & \multicolumn{2}{|c|}{$56.2,92.0 \%$} & $609 \mathrm{mV}$ & $0.94 \mathrm{~W} / \mathrm{m}^{2}$ & 126 \\
\hline $\begin{array}{c}\text { AEM, DF120, } \\
\text { Tianwei }\end{array}$ & $\begin{array}{l}\text { CEM, Ultrex } \\
\text { CMI7000, } \\
\text { Membrane } \\
\text { International) }\end{array}$ & $\begin{array}{l}\text { carbon } \\
\text { graphite } \\
\text { fiber } \\
\text { brushes }\end{array}$ & $\begin{array}{l}\text { carbon } \\
\text { cloth( } \\
\text { with } \\
\text { platinum) }\end{array}$ & $\begin{array}{r}\text { xylose } \\
(1 \mathrm{~g} / \mathrm{l})\end{array}$ & $20 \mathrm{~g} / \mathrm{l} \mathrm{NaCl}$ & $50 \mathrm{mM}$ PBS & $\begin{array}{c}12 \%, \text { Salt } \\
\text { removal: } \\
97 \pm 1 \% \text { at } \\
\text { an HRT = } 2 \\
\text { days } \\
76 \pm 1 \% \text { at } \\
\text { an HRT = } 1 \\
\text { day }\end{array}$ & & & $\begin{array}{c}860 \pm 11 \\
\mathrm{~mW} \mathrm{~m}^{2}\end{array}$ & 127 \\
\hline $\begin{array}{c}\text { AMI-7001, } \\
\text { Membranes } \\
\text { International } \\
\text { Inc., }\end{array}$ & $\begin{array}{l}\text { CMI-7000, } \\
\text { Membranes } \\
\text { International } \\
\text { Inc }\end{array}$ & $\begin{array}{l}\text { carbon } \\
\text { fiber felt }\end{array}$ & $\begin{array}{l}\text { carbon } \\
\text { fiber felt }\end{array}$ & & $\begin{array}{c}700,100 \\
\mathrm{mg} / \mathrm{l}\end{array}$ & $\begin{array}{l}\text { with potas- } \\
\text { sium } \\
\text { ferricyanide, }\end{array}$ & & & & $\begin{array}{c}360 \\
\mathrm{~mW} / \mathrm{m}^{2}\end{array}$ & 128 \\
\hline $\begin{array}{l}\text { AEM, Mem- } \\
\text { branes } \\
\text { International }\end{array}$ & $\begin{array}{c}\text { CEM, } \\
\text { Membranes } \\
\text { International }\end{array}$ & Carbon brush & $\begin{array}{l}\text { Carbon } \\
\text { cloth+Pt }\end{array}$ & $\begin{array}{l}\text { Treated } \\
\text { WW from } \\
\text { OsMFC } \\
\text { with } 1 \mathrm{~g} / \mathrm{l} \\
\text { Sodium } \\
\text { acetate }\end{array}$ & $\begin{array}{c}10-35-50 \\
g / l \text { (catholyte } \\
\text { of OsMFC }\end{array}$ & $\begin{array}{l}\text { Acidified } \\
\text { water, } \\
\text { salt water, } \\
\text { anode } \\
\text { effluent }\end{array}$ & $95 \%-85 \%$ & $85 \%$ & & $12.45 \mathrm{~W} / \mathrm{m}^{3}$ & 129 \\
\hline $\begin{array}{c}\text { AEM, AMI- } \\
7001, \\
\text { Membrane } \\
\text { International }\end{array}$ & $\begin{array}{l}\text { CEM, CMI- } \\
7000, \\
\text { Membrane } \\
\text { International }\end{array}$ & Carbon brush & $\begin{array}{l}\text { Carbon } \\
\text { Cloth+Pt }\end{array}$ & $2 \mathrm{~g} / \mathrm{l}$ & $6 \mathrm{~g} / \mathrm{l}$ & $\begin{array}{l}\text { Acidified } \\
\text { water }\end{array}$ & $42 \%-58 \%$ & NA & $\begin{array}{c}3 \mathrm{MDC} \text { in } \\
\text { Series }=3.25 \\
\mathrm{~V}, 3 \mathrm{MDC} \text { in } \\
\text { parallel }=1.14 \\
\mathrm{~V}\end{array}$ & $\begin{array}{l}72 \mathrm{~mW} \\
62 \mathrm{~mW}\end{array}$ & 130 \\
\hline
\end{tabular}

Table 1: Materials and performances of MDC studies. 
wastewater to desalination chamber) promotes proton transport from anode side into the middle chamber. Further investigations are required to address problems with MODCs. For instance, the membrane fouling and the lack of selectively separating anions by $\mathrm{FO}$ membrane results in decrease in the rate of overall ionic separation [44]. The MDC outperformed MODC in desalination capacity and this was attributed to the FO membrane that disabled migration of chloride ions to the anode chamber, and thereby creating ionic imbalance between $\mathrm{Na}^{+}$ and $\mathrm{Cl}^{-}$ions. Also, the water transport in MODC can, sometimes, turn out to be a water contamination problem if the contaminants from the anode chamber pass through the AEM to the desalination chamber.

MDCs possess a potential to provide side streams of acid and alkali solutions [70]. In one study, a bipolar membrane was inserted next to the anode chamber in MDC. The water dissociates between two layers by the supply of external electric field resulting in the migration of $\mathrm{H}^{+}$ through the cation exchange membrane layer forming $\mathrm{HCl}$, and $\mathrm{OH}^{-}$ through the anion exchange membrane layer which aids in maintaining constant $\mathrm{pH}$ in the anode chamber. Salt water is desalinated in the middle chamber so that $\mathrm{NaOH}$ is produced in the cathode chamber. A limitation of this system is that the desalination capacity is directly dependent upon the applied voltage. The extent of desalination in four chamber bipolar membrane MDC has been observed to be higher than the regular MDC due to the $\mathrm{pH}$ balance. Even with the external voltage requirements, MDCs can be cost efficient due to its potential to produce valuable commodity chemicals such as hydrochloric acid.

The current density in MDCs is significantly lower than other MXCs. This can be attributed to the conductivity issues related to wastewater and ion migration in the MDC chambers. For example, ionic species (e.g. $\mathrm{NO}_{3}{ }^{-}$and $\mathrm{SO}_{4}{ }^{2-}$ ) migrate from saline water to the anolyte and compete at the anode as the electron acceptors, and result in reduction of overall electric current in MDCs. In addition, the variation in charge and molecular size of typical ions affects thetransport behavior of ions in the MDCs. It has been observed that the MDC performance decreased by $22 \%$ when artificial seawater was replaced with pure $\mathrm{NaCl}$ in MDCs. This indicates that the desalination efficiency can be low when MDCs are used for practical applications that require desalination of actual seawater and wastewater [73]. This is evident from the fact that the current state-of-art MDC technology delivers nearly $\sim 90 \%$ desalination efficiency using salt solution $(\mathrm{NaCl}$ upto $35 \mathrm{~g} / \mathrm{L}$ ), while the desalination efficiency has been reported to be just $50 \%$ with synthetic seawater. However, it is certain that the MDC technology can be used as a pretreatment unit for a downstream reverse osmosis (RO) process.

To summarize, a series of fundamental studies are warranted to address current issues in MDC technology. The current state-of-artMDC designs use a large ratio of anode/desalination chamber volumes, and cathode/desalination chamber volumes. Salinity removal of greater than $90 \%$ in MDCs requires a desalination and electrolyte (anode and cathode) volume ratio of around 1: 13-66 [74]. Ratio of design volumes for anode, cathode and desalination chambers is an important parameter which determines the distance between the two electrode compartments and the corresponding ohmic losses. The $\mathrm{pH}$ fluctuations in the MDCs are also a significant problem. The introduction of anion exchange membranes (AEMs) and cation exchange membranes (CEMs) induces resistance to ion transport transfer between the respective chambers in MDCs. The application of a membrane results in a higher energy input to overcome the electrochemical losses due to the increased $\mathrm{pH}$ gradient and ohmic losses. Further, the membrane properties (e.g charge density) influence the ion transport characteristics in MDCs [75]. Recirculation of electrolyte between anode and cathode chambers may bring down the $\mathrm{pH}$ fluctuations in MDCs, but at the expense of undesirable side reactions that impede power generation capability in MDCs. The microbial desalination process involves complex network of ionic species transport from one chamber to the other via exchange membranes, and inherent issues of ionic, electron and mass transport will become inevitable [73].

\section{Integration of MDCs with algae harvesting systems}

Most of the MDC studies used synthetic wastewater to evaluate the desalination performance, the possible organic removal rates, and energy production; however, it is critical to extend this experience with systems using real wastewater. Luo et al. [42] tested MDCs using wastewater in the anode compartment. When using wastewater as the sole substrate, the power output from the MDC $\left(8.01 \mathrm{~W} / \mathrm{m}^{3}\right)$ was four times higher than a control MFC without desalination function. In addition, the MDC removed $66 \%$ of the salts and improved COD removal by $52 \%$ and Coulombic efficiency by $131 \%$. Desalination inMDCs improved wastewater characteristics by increasing the conductivity by 2.5 times and stabilizing anolyte $\mathrm{pH}$, and thereby reducing system resistance and maintaining microbial activity. Microbial community analysis revealed a more diverse anode microbial structure in the MDC than in the MFC. The results demonstrated that MDC can serve as a viable option for integrated wastewater treatment, energy production, and desalination [42]. It is therefore practical to integrate microbial desalination cells with existing wastewater treatment systems (Figure 2). MDCs can operate as a standalone integrated wastewater treatment - desalination systems, or they can be combined with anaerobic or aerobic wastewater treatment systems to feed on digester effluents.

Integrated wastewater treatment, desalination, and algal growth systems can be considered for efficient management of the microbial desalination systems. Introducing algae in the cathode chamber can increase the electron mobility in the electrical circuit due to increased dissolved oxygen concentrations caused by in-situ oxygen release by algae $[76,77]$. Traditional wastewater treatment technologies are energy consuming, with large quantities of $\mathrm{CO}_{2}$ released into the atmosphere during the degradation process of organic pollutants. About 15,000 tons of $\mathrm{CO}_{2}$ is released per 1,000 tons of wastewater treated. If the $\mathrm{CO}$

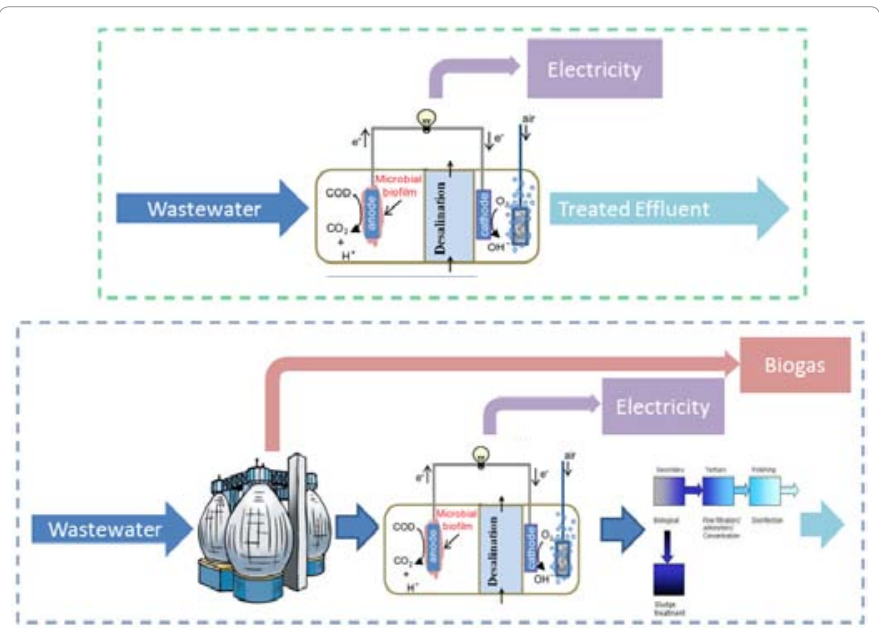

Figure 2: Integration of Microbial Desalination cell (MDC) with wastewater treatment. 
Citation: Gude VG, Kokabian B, Gadhamshetty V (2013) Beneficial Bioelectrochemical Systems for Energy, Water, and Biomass Production. J Microb Biochem Technol S6: 005. doi:10.4172/1948-5948.S6-005

Page 7 of 14

can be captured and supplied to the cathode chamber as substrate for the algal cell growth, this will result in high value algal biomass and such process can be considered as sustainable process [78]. Since reduction of oxygen in cathode chamber results in hydroxide release andraises $\mathrm{pH}, \mathrm{CO}_{2}$ recycling will control the $\mathrm{pH}$ rise. On the other hand, nutrient removal using microbial fuel cells has not been given much attention so far. There are only a few MFC studies that focused on this aspect of the wastewater treatment. Further, MFCs have limited capability to remove nutrients such as phosphorus from wastewater. Considering the above two concerns, an ideal solution would be to introduce an algal bio-cathode to sequester $\mathrm{CO}_{2}$ and organic substrates released from the anode chamber along with nutrients to be consumed by algae. Algae have a composition of C: N: P ratio of 50:8:1 while domestic wastewater has a composition of 20:8:1 [79]. With addition of carbon source $\left(\mathrm{CO}_{2}\right)$, wastewater can serve as excellent medium for algal growth. Microalgae assimilates nitrogen and phosphorus into their biomass as well as carbon dioxide for photosynthesis and produce oxygen, and the net biomass produced in this process can be used for the production of valuable products (e.g., biodiesel, fertilizer). The capability of algae to facilitate electron transfer from substrates to the electrodes (in anode) as well as from electrode to the reducing species (in cathode) is not clear. But, an algal harvesting and anaerobic digester system was studied recently. This system transforms solar energy into energy-rich biogas and electricity. Algal productivities of 24-30 ton VS (volatile solids or organic dry matter) per hectare per year were reached, while $0.5 \mathrm{~N} \mathrm{~m}^{3}$ biogas could be produced per $\mathrm{kg}$ of algal VS [80].

\section{Integration of MDCs with ground water treatment}

MDCs can be utilized to treat groundwater with high hardness and other environmental pollutants. A new concept of non-invasive treatment method for removing nitrates from the ground water in MDCs has been proposed recently [81]. This system offers a unique benefit of non-source pollution and complete removal of nitrates in a submerged microbial desalination cell system. The feasibility of removing hardness compounds from groundwater was tested with hard water samples ranging from 220 to $2080 \mathrm{mg} / \mathrm{L}$ as $\mathrm{CaCO}_{3}$. It was found that the MDC generally removed more than $90 \%$ of the hardness from the tested water samples driven by electron movement in batch operation. Electricity production was highly related to the conductivity of the hard water samples. In this study, the following reductions were achieved by the MDCs: $89 \%$ of the arsenic; $97 \%$ of the copper; $99 \%$ of the mercury; and $95 \%$ of the nickel at the testing concentrations in a synthetic solution [82].

\section{Energy Evaluation of MDC Technology}

The U.S. utilizes about $5 \%$ of total energy to treat water and wastewater resources. Wastewater treatment requires about $0.5-2$ $\mathrm{kWh}$ of energy per unit depending on the process and interestingly, wastewater contains about the 10 times more energy than it is required to treat. Capturing this energy could result in a sustainable wastewater treatment solution. Energy locked in wastewater is mainly present in three forms: i) organic matter $\left(\sim 1.79 \mathrm{kWh} / \mathrm{m}^{3}\right)$, ii) nutrients such as nitrogen, phosphorous $\left(\sim 0.7 \mathrm{kWh} / \mathrm{m}^{3}\right)$, and iii) thermal heat $(\sim 7 \mathrm{kWh} /$ $\mathrm{m}^{3}$ ) [83]. Chemical energy can be efficiently harvested while thermal heat may not be extracted except by use of a heat pump and is further subjected to wastewater source temperature. By extracting this hidden chemical energy in wastewater, wastewater treatment can be turned into an energy-producing process rather than an energy consuming process while eliminating environmental pollution.
Contrary to conventional desalination methods, MDC is considered energy gaining process. The microbial desalination cells produce bioelectricity while desalinating the saline water. It is estimated that about $1.8 \mathrm{kWh}$ of bioelectricity can be generated in MDCs by treating $1 \mathrm{~m}^{3}$ of wastewater while a reverse osmosis technology requires 2.2 $\mathrm{kWh}$ of electricity for the same amount of water desalination. This suggests that desalination combined with MDCs has the potential to become sole power generator along with wastewater treatment. Combining the energy produced by the MDCs and the energy saved by the desalination, a total $4 \mathrm{kWh} / \mathrm{m}^{3}$ of energy savings can be realized (Figure 3). In a case where UMDC is utilized as a pretreatment process for RO process, MDCs can reduce $30 \%$ of dissolved solids which will reduce the RO energy requirements from 3.7 to $3.5 \mathrm{kWh} /$ $\mathrm{m}^{3}$. However, majority of the MDC studies are based on synthetic salt whose composition may be far different from real brackish and seawater sources and wastewater sources [45]. In studies involving hydrogen production, it was determined that the MDC or MEC system has recovered 2.3 times more energy than that was invested originally [40]. In systems integrated with algal harvesting, the energy recovery benefits could be even higher since algae have an energy content of $5-8 \mathrm{kWh} / \mathrm{kg}$ dry weight. This energy can be recovered in the form of biofuels such as biogas, biohydrogen, and biodiesel [84].

\section{Comparison of MDCs with Conventional Desalination Technologies}

Desalination is a well-recognized technology for obtaining freshwater in many parts of the world. The recent technological innovations have resulted in a significant reduction in energy costs associated with desalination technologies. Current desalination technologies (both membrane and thermal based technologies) are energy-intensive. Minimum theoretical energy required for separating

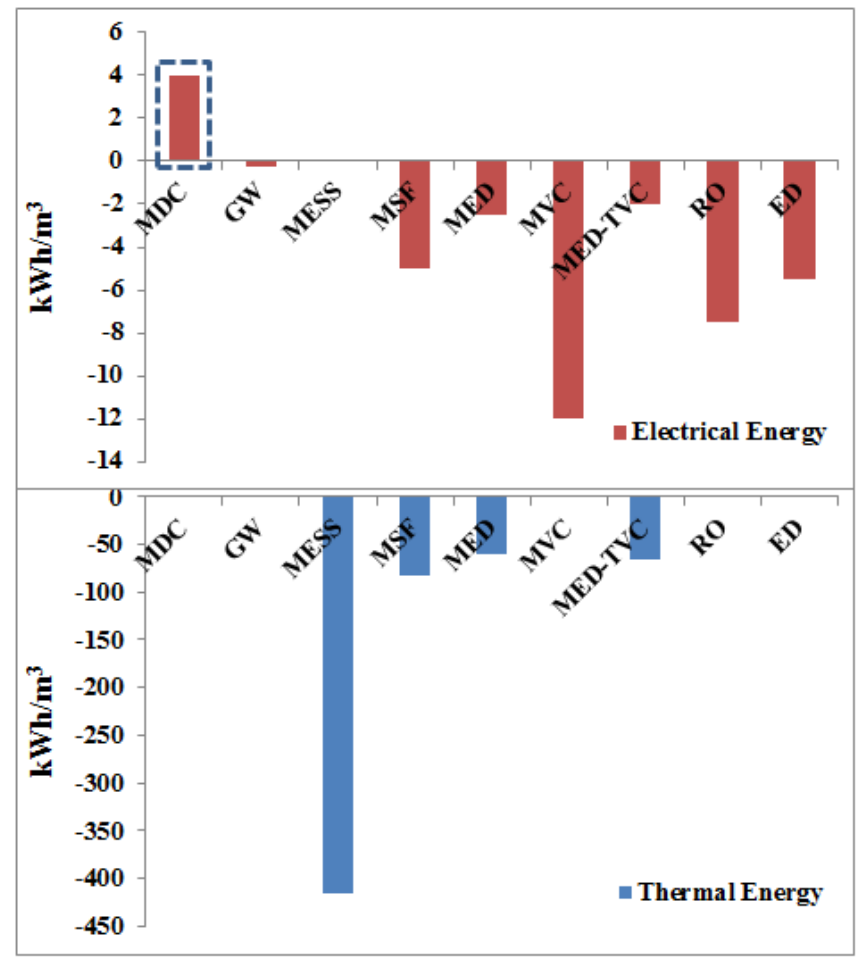

Figure 3: Net energy gain for different desalination processes. 
the salts from seawater to produce freshwater is $0.706 \mathrm{kWh} / \mathrm{m}^{3}$ [85]. In practice, much higher energy is required by currently available desalination technologies. In terms of magnitude, about 1 ton of oil is required for every 20 tons of freshwater produced even if all the heat can be extracted from the oil $[86,87]$. The energy requirements for different desalination processes are shown in Figure 3. Negative energy values indicate consumption or requirement by the process. Well established desalination technologies such as MSF - multi-stage flash distillation; MED - multi-effect distillation; MVC - mechanical vapor compression; RO - reverse osmosis; ED - electrodialysis; MESS - multi-effect solar still require large quantities of energy in the form of thermal and/or electrical energy (Figure 3). The most energyefficient reverse osmosis desalination systems still consume 3-4 kWh/ $\mathrm{m}^{3}$ of desalinated water. The technology advancements and research in utilization of efficient system design, high efficiency pumping, and energy recovery devices has been studied extensively and near optimal performance characteristics have already been established. Further design improvements in these categories will only provide marginal reduction in energy consumption [88]. Research avenues that show the most promise for reducing energy usage lie in the development and testing of novel desalination technologies with reduced feed pressure requirements such as microbial desalination cells. In microbial desalination cells, external energy is not consumed rather additional energy is produced while providing wastewater treatment and water desalination simultaneously [36].

\section{Othe 'Mxc' Applications}

As described earlier, MXCs refer to bioelectrochemical systems that share the principles of MFCs, with a slight variation in the anode and/or cathode configuration. For instance, MFCs can be modified to obtain microbial electrolysis cells (MECs) and microbial solar cells (MSCs). The cathodes in MECs can be used to produce valuable energy carriers (e.g. $\mathrm{H}_{2}$ and $\mathrm{CH}_{4}$ ) by incorporating principles of electrolysis in MFCs [89]. In MSCs, the anode and/or cathode chamber is populated with photosynthetically-active bacteria or algae or plants to produce valuable organic compounds in the anode, dissolved oxygen in the cathode, and finally, DC electric power output. MDCs address the environmental issues related to wastewater treatment, bioremediation, and desalination; MSCs use algae, photosynthetic bacteria, and plants, to obtain a sustainable technology for carbon sequestration. MSCs are highly valued because they use solar energy to obtain a simple and affordable technique for sequestering carbon. The following sections provide a critical insight on the scientific principles and operational issues related to algae-based MXCs, and microbial solar cells (MSCs).

\section{Algae-based MXC}

Algae-based MFCs mimic syntrophic relationship between photosynthetic bacteria and algae commonly observed in natural water bodies. For instance, during sunlight hours, algae convert carbon dioxide into organic matter and simultaneously release oxygen. The benthic heterotrophs degrade the organic matter (i.e. naturally evolving from algae and anthropogenic waste) into carbon dioxide and water. The resulting carbon dioxide is utilized by algae to produce organic matter and oxygen. Similarly, the algae play an important role in nitrogen and phosphorus cycles in natural water (Figure 4). It has been recently hypothesized that the natural systems can be engineered to reap the benefits of energy production and water treatment by using MXCs technology. In particular, the electrochemical reactions occurring between the microorganisms and algae have been reported to generate electricity that can be captured in microbial fuel cells [90].

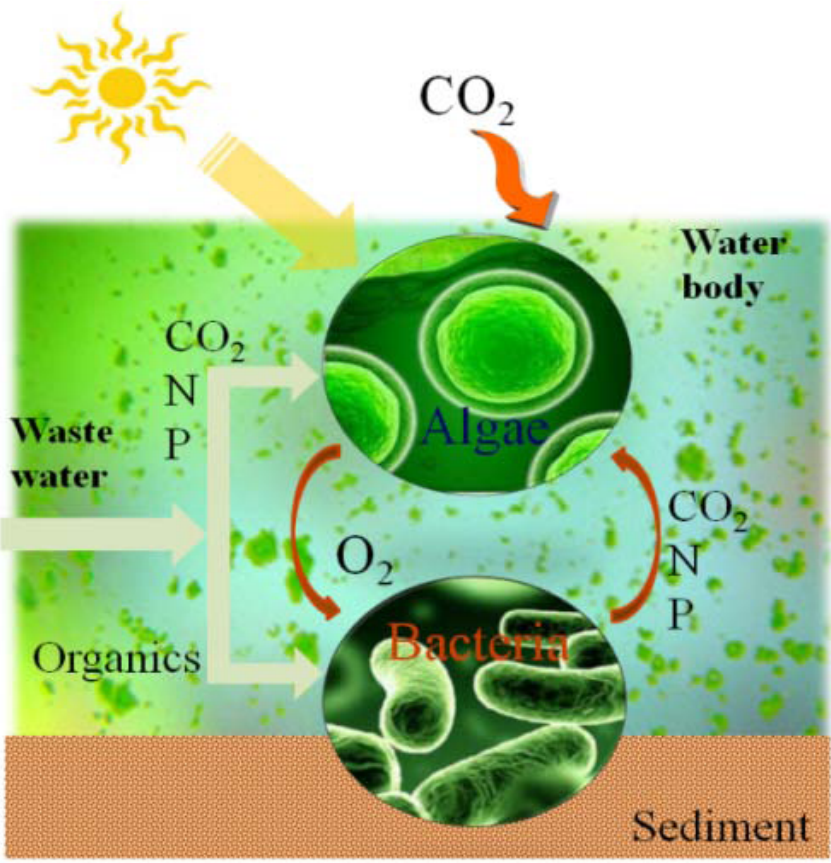

Figure 4: Algae-based microbial fuel cells in environmental applications.

Thus, algae can be used to treat biodegradable matter and nutrients in MFCs with minimal net energy input.

In MFCs designed for wastewater treatment, the effluent from the anode chamber can be used as a growth medium for the algal biomass to obtain following advantages: 1) the effluent from the anode chamber saturated with carbonate system can be readily converted by algae into organic matter; 2) nitrates and ammonia nitrogen in the effluent can enhance the cell production; 3) phosphorous compounds may be absorbed by the cell and utilized in cell growth; 4) algae in turn release oxygen which could be readily available as electron acceptor; 5) continuous flow configuration alleviates the $\mathrm{pH}$ fluctuations in both the chambers; and 6) algal biomass can be used for a variety of high value bio-products and fuel generation.

Role of Algae in MXCs: Algae in bioelectrochemical systems can be used to: i) serve as electron donor (at anode); ii) remove organic matter (heterotrophic algae at anode); and iii) produce electron acceptor (photosynthetic algaeat cathode). The photosynthetic microalgae (Chlorella vulgaris) have been recently used in cathodic half cells in microbial fuel cells [91-93]. Growth kinetics of Chlorella vulgaris suggested an optimum value of dissolved $\mathrm{CO}_{2}$ concentration as higher $\mathrm{CO}_{2}$ concentrations have resulted in inhibitory effects [91] These studies used Saccharomyces cerevisiae in the anode chamber. The Chlorella sp. is generally preferred for carbon sequestration because of their tolerance for high levels of $\mathrm{CO}_{2}$ and high efficiency in utilizing $\mathrm{CO}_{2}$ through photosynthesis. C. vulgaris in MFCs in combination with $S$. cerevisiae fermentation can result in both bioethanol and bioelectricity production. The practical problem with this system is that the growth rate of $S$. cerevisiae is significantly higher than the growth rate of C. vulgaris. This phenomenon may retard high current densities and reliable current flow. This issue was addressed later by developing a continuous flow microbial fuel cell system to recycle algae cells to increase their density which eventually increased the power production [93]. Table 2 provides details on algae based microbial fuel cells studies. 
Citation: Gude VG, Kokabian B, Gadhamshetty V (2013) Beneficial Bioelectrochemical Systems for Energy, Water, and Biomass Production. J Microb Biochem Technol S6: 005. doi:10.4172/1948-5948.S6-005

Page 9 of 14

Marine algae have been demonstrated as viable electron donors in MFC application. For instance, Velasquez et al. used two types of marine algae in dry powder form (microalgae - Chlorella vulgaris and macroalgae - Ulva lactuca) as the sole feedstock in the anode chamber of microbial fuel cells. They reported that the $C$. vulgaris microalgae recovered more energy per substrate $(2.5 \mathrm{~kW}-\mathrm{h} / \mathrm{kg}$-Dry Weight) compared to U. lactuca (2.0kW-h/kg- Dry Weight) and hence COD removal was much better. The maximum power densities in their experiments reached as high as $0.98 \mathrm{~W} / \mathrm{m}^{2}\left(277 \mathrm{~W} / \mathrm{m}^{3}\right)$ [94]. Similarly, Gadhamshetty et al. have demonstrated the use of unprocessed algae (Laminaria) as a feedstock in MFC applications. They found that the salt content associated with marine algae can boost MFC performance by increasing the solution conductivity and reducing ohmic resistance [95].

\section{Microbial Solar Cells - MSCs (Photosynthetic-MFCs)}

The microbial solar cells (MSCs) is another version of MFCs that are fueled by in-situ photosynthesized metabolites from algae, cyanobacteria, or living higher plants. Microbial solar cells involve the following major steps: 1) production of organic matter by photosynthetic- active bacteria or algae; 2) anodic oxidation of organic matter by electrochemically active bacteria; and 3) cathodic reduction of oxygen. The only energy input in MSCs is solar energy $[96,97]$. The earlier section (section 6.1) described the innovative role of photosynthetic microbes as electron acceptors in the biocathode.
In MSCs, these microorganisms are employed in anode chamber for generating organic matter. Considering that sunlight offers an unlimited source of energy, development of self-sustainable microbial fuel cells that rely on light instead of pure organic matter as an energy source has become an increasingly popular area of research in recent years [98-101]. This renders MSCs as an alternative to develop a self-sustainable machine for energy production. In addition, due to photosynthetic carbon sequestration, they offer a sustainable pathway to produce carbon-neutral energy [102].

The MSCs can be classified into four groups based on the photosynthetic microbes used in the anode chamber: i) sub-cellular, ii) prokaryotic (cyanobacteria), iii) eukaryotic (algae), and iv) mixed systems. Use of sub-cellular organelles has included thylakoid membranes [103], photosystems (PS1 and PS2) [104,105], bacterial reaction centre [106] and isolated chlorophyll and its derivatives [107]. However, lifetimes of MSCs incorporating organelles are short as organelles cannot self-repair. This is a major disadvantage, and makes the use of whole cells highly advantageous [108]. Recently, Strik et al have categorized the MSCs based on the mechanism of solar energy utilization and the mode of organic matter transfer: i) a higher plant with rhizodeposition; ii) a phototrophic biofilm; or a iii) photobioreactor, which use pumps for translocation. The in-depth bioelectrochemical principles of all the MSCs are yet to be fully revealed. Figure 5 provides an overview of recent trends in current and power

\begin{tabular}{|c|c|c|c|c|c|c|c|}
\hline $\begin{array}{c}\text { Electron } \\
\text { Donor (Anode) }\end{array}$ & Anode Chamber & Cathode Chamber & $\begin{array}{l}\text { Power } \\
\text { Density }\end{array}$ & $\begin{array}{l}\text { OCV } \\
(\mathrm{mV})\end{array}$ & CE & $\begin{array}{c}\text { COD } \\
\text { Removal }\end{array}$ & Ref. \\
\hline- & $\begin{array}{l}0.02 \mathrm{M} \text { potassium } \\
\text { ferrocyanide }\end{array}$ & $\begin{array}{l}\text { C. Vulgaris/ } \\
\text { methylene blue }\end{array}$ & $2.7 \mathrm{~mW} / \mathrm{m}^{2}$ & 70 & NA & NA & 91 \\
\hline- & S. Cerevisiae & Chlorella vulgaris & $0.95 \mathrm{~mW} / \mathrm{m}^{2}$ & 315 & NA & NA & 92 \\
\hline $20 \mathrm{~g} / \mathrm{l}$ glucose & S. Cerevisiae & Chlorella vulgaris & $0.6 \mathrm{~mW} / \mathrm{m}^{2}$ & 220 & NA & NA & 93 \\
\hline $1 \mathrm{~g} / \mathrm{l}$ glucose & Mixed culture & Chlorella/Phormidium & $0.8 \mathrm{~mW} / \mathrm{m}^{2}$ & - & $0.05 \%$ & $89 \%-32.9 \%$ & 131 \\
\hline $1 \mathrm{~g} / \mathrm{l}$ glucose & $\begin{array}{l}\text { Enriched microbes } \\
\text { from wastewater }\end{array}$ & Chlorella vulgaris & $5.6 \mathrm{~W} / \mathrm{m}^{3}$ & 805 & $85 \%$ & $94 \%$ & 78 \\
\hline $\begin{array}{l}\text { Acetate/alga } \\
\text { lyses }\end{array}$ & Chlorella & $\begin{array}{l}50 \mathrm{mM} \text { potassium } \\
\text { hexacyanoferrate }\end{array}$ & $110 \mathrm{~mW} / \mathrm{m}^{2}$ & 705 & $2.80 \%$ & NA & 121 \\
\hline $0.2 \mathrm{~g} / \mathrm{l}$ acetate & $\begin{array}{c}\text { Sediment (water } \\
\text { content } 25 \% \text { ) }\end{array}$ & Chlorella vulgaris & $69 \mathrm{~mW} / \mathrm{m}^{2}$ & - & - & $99.60 \%$ & 132 \\
\hline $\begin{array}{l}\text { Chlorella } \\
\text { vulgaris }\end{array}$ & $\begin{array}{c}\text { Algae powder+ } \\
\text { primary clarifier } \\
\text { overflow }\end{array}$ & Oxygen/platinum & $0.98 \mathrm{~W} / \mathrm{m} 2$ & - & $28 \%$ & $60.60 \%$ & 94 \\
\hline Ulva lactuca & $\begin{array}{l}\text { Algae powder+ } \\
\text { primary clarifier } \\
\text { overflow }\end{array}$ & Oxygen/platinum & $0.76 \mathrm{~W} / \mathrm{m}^{2}$ & - & $23 \%$ & $73.10 \%$ & 94 \\
\hline Laminaria & $\begin{array}{l}\text { Raw Algae+ mixed } \\
\text { microbial } \\
\text { population from the } \\
\text { primary clarifier } \\
\text { overflow }\end{array}$ & $50 \mathrm{mM}$ ferricyanide & $0.25 \mathrm{~W} / \mathrm{m}^{2}$ & 700 & $<5 \%$ & $42-88 \%$ & 95 \\
\hline $\begin{array}{l}\text { effluent of the } \\
\text { anaerobic } \\
\text { digester }\end{array}$ & $\begin{array}{l}\text { effluent of the } \\
\text { anaerobic digester }\end{array}$ & $\begin{array}{l}\text { Chlamydomonas } \\
\text { reinhardtii and } \\
\text { Pseudokirchneriella } \\
\text { subcapitata }\end{array}$ & $0.25 \mathrm{Wm}^{-3}$ & & $40 \%$ & $37 \%$ & 80 \\
\hline $\begin{array}{l}\text { Autoclaved LB } \\
\text { media }\end{array}$ & Shewanella putrefaciens & $\begin{array}{c}\text { Cyanobacteria (Anabaena } \\
\text { strain) }\end{array}$ & $\begin{array}{l}52.81 \mathrm{~mW} / \mathrm{m}^{2} \\
76.05 \mathrm{~mW} / \mathrm{m}^{2} \\
100.1 \mathrm{~mW} / \mathrm{m}^{2}\end{array}$ & $\begin{array}{l}698 \\
734\end{array}$ & & & 133 \\
\hline $1.0 \mathrm{~g} / \mathrm{l}$ glucose & anaerobic sludge & Chlorella vulgaris & $\begin{array}{c}2485.35 \\
\mathrm{mWm}^{3}\end{array}$ & & $9.40 \%$ & $84.80 \%$ & 134 \\
\hline- & $\begin{array}{l}\text { Rhodospirillum } \\
\quad \text { rubrum }\end{array}$ & $\begin{array}{c}\text { blue-green marine } \\
\text { algae, } \\
\text { Oscillatoriaceae, }\end{array}$ & NA & $0.96 \mathrm{v}$ & - & - & 119 \\
\hline
\end{tabular}

Table 2: Use of algae in bioelectrochemical systems. 
densities generated in MSCs using plants (A), photosynthetic biofilms (B), and photobioreactors (C) [109]. A maximum of $0.01 \%$ power conversion efficiency was reported in these studies. Figure 5a shows that the Ferricyanide has produced more power but it can be noted that oxygen has also shown comparable current and power production in one of the studies. Figure $5 b$ shows the current and power densities for phototrophic biofilm studies using oxygen with and without platinum catalysts and Ferricyanide. Figure $5 c$ shows high current and power densities reported by studies involving photobioreactors.

\section{Plant based photosynthetic microbial fuel cells}

The living plants use solar energy to fix carbon dioxide in the form of carbohydrates and some of the fixed carbon is transferred to the roots of the plant with time. The plant root system produces and releases different types of organic compounds into the soil, which include (1) exudates: sugars, organic acids, etc.; (2) secretions: polymeric carbohydrates and enzymes; (3) lysates: dead cell materials; and (4) gases: ethylene and $\mathrm{CO}_{2}[110]$. All these products form rhizodeposits, which are used in the plant-MFC as a renewable bioenergy substrate. Rhizodeposits contain carbon and a part of this carbon can be utilized by micro-organisms in the rhizosphere, which can lead to mutually beneficial interactions between plants and micro-organisms. Bacteria, for example, can positively interact with plant roots by forming

O $\quad \mathrm{O}_{2} ; \mathrm{P} \quad \mathrm{O}_{2}$ /Platinum; $\mathrm{F} \quad$ :Ferricyanide
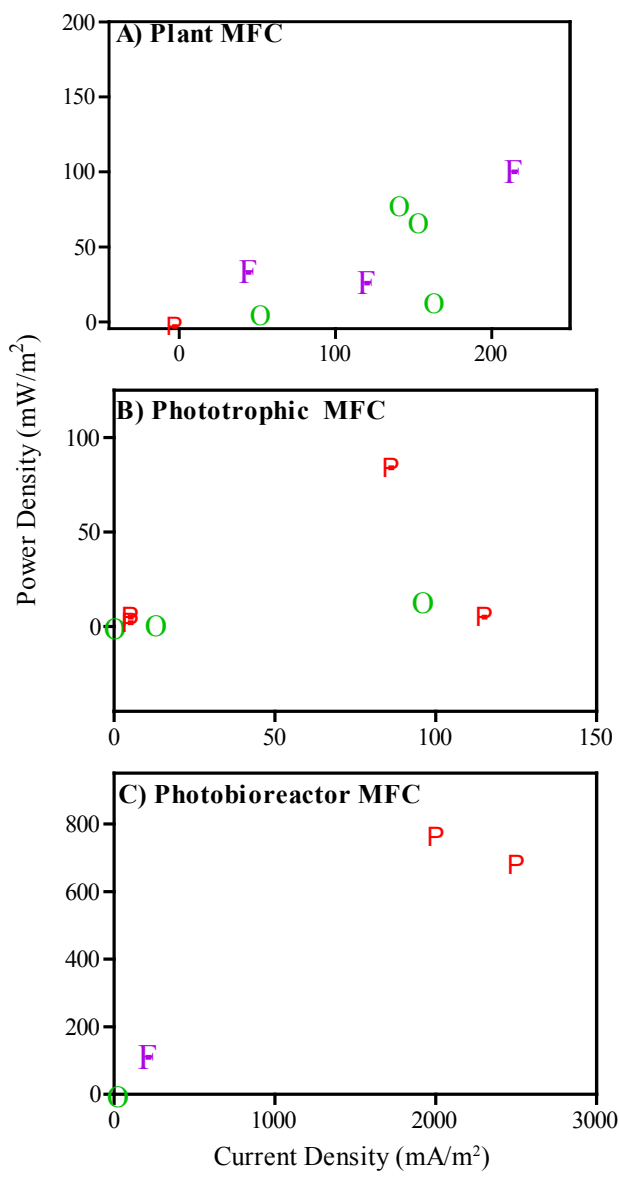

Figure 5: Performance comparison of: A) Plant-MFCs; B) Photo-biofilm MFCs; and C) PBR based MFCs. protective biofilms or by producing antibiotics as biocontrols against potential pathogens [111]. In the plant-MFC, the principal idea is that plant rhizodeposits are utilized as substrates by the bacteria to generate electricity in the microbial fuel cell. Proof of principle and concept studies were performed to produce renewable electricity via living higher plants in MFCs [96,110-113].

Algal photosynthetic microbial fuel cells (p-MFCs): Algae can serve as excellent photo electrochemical energy harvesting factories. Unlike electrochemically active bacteria, electron transport in algae to an electrode has been considered difficult. This has been attributed to the lack of conductive extracellular matrices in algae. Use of nanoelectrodes to collect high energy electrons was demonstrated but this method may result in large scale application issues. Another way to overcome electron transport issue is to use mediators in the solution. But this will cause short-circuiting reactions which occur between the reduced form of mediator and photo- synthetically evolved oxygen reducing p-MFC efficiency. Although use of mediators in the anode chambers is troublesome, the same is beneficial in the cathode chamber [91,114-119].

Algal based photosynthetic systems have been more popularly used in mixed cultures where algae live in synergistic cooperation with electrochemically active bacteria. This fact was believed to be the cause for the p-MFC systems to produce high power production without addition of electron mediators. The electrochemically active bacteria are heterotrophs which utilize the organic products released by the algae and algae utilize the products produced by these bacteria as explained before [90,120-121].

Many other natural photosynthetic biofilms studies and sediment type p-MFCs used photo-biocathodes and/or photo-bioanodes composed of uncharacterized photosynthetic natural biofilms, most likely containing algae [120,98-101]. Although high current densities were obtained with some systems (for example, a p-MFC containing a natural a pond biofilm and polyaniline coated anodes produced 5.9 $\left.\mathrm{mW} \mathrm{m} \mathrm{m}^{-2}[101]\right)$, as the photosynthetic material was uncharacterized, the studies are irreproducible by other groups. Overall, it can be seen that $\mathrm{p}$-MFC research is at its infant stage, and much is required to discover electron transfer mechanism and cellular behaviour. In contrast, if the p-MFC consists of a pure culture in a simple set-up, then it can be characterized extensively. Throne investigated the interaction of algae and its photosynthetic activities with potassium ferricyanide to answer some of these fundamental questions [102].

\section{Photobioreactors}

Strik et al. [122] developed a photosynthetic algal microbial fuel cell (PAMFC) using algae cultures from an open system and electrochemically active bacteria as low-cost self-sustaining catalysts with graphite electrodes. This system was tested continuously for over 100 days and a maximum current density of $539 \mathrm{~mA} / \mathrm{m}^{2}$ projected anode surface area and a maximum power production of $110 \mathrm{~mW} / \mathrm{m}^{2}$ photobioreactor surface area were obtained. This system achieved a photosynthetic efficiency of $6.3 \%$ (photobioreactor) which was $42 \%$ of the expected maximum with an overall system efficiency of $0.1 \%$. The study reported that the energy recovery of the PAMFC can be increased by optimization of the photobioreactor; by reducing the competition from non-electrochemically active microorganisms; by increasing the electrode surface; and by establishment of a further-enriched biofilm.

An integrated process combining an algae photobioreactor, microbial fuel cell, and an anaerobic digester was studied by De 
Schamphelaire and Verstraete [80]. In this system, algae was allowed to grow in a photobioreactor under illumination, and algal biomass was circulated through an anaerobic digester to produce biogas by biomass degradation into smaller organic compounds (digester supernatant) which in turn were circulated through the anode chamber as a substrate source for MFC. The living algal biomass was circulated through the anode chamber to provide oxygen source. This system produced biogas (methane) along with clean bioelectricity.

Photobioreactors can also be designed to provide advanced treatment of wastewater. Jiang et al developed a photobioreactor system to remove nutrients from wastewater. The effluent from the cathode chamber of a sequential anode-cathode microbial fuel cell was circulated through an external photobioreactor to remove phosphorous and nitrogen by using microalgae. The photobioreactor has produced a maximum power of $20.3 \mathrm{~W} / \mathrm{m}^{3}$, and the integrated system removed $92 \%$ of total phosphorous (TP) and $99 \%$ ammonia nitrogen $\left(\mathrm{NH}_{4}-\mathrm{N}\right)$. These results demonstrate both the effectiveness and the potential application of the coupled system to continuously treat domestic wastewater and simultaneously generate electricity [123]. This group also developed a membrane-less upflow MFC combined with a photobioreactor and obtained total phosphorous and nitrogen removal efficiencies of $99.3 \%$ and $99.0 \%$ respectively [124].

The operational challenges encountered in Microbial solar cells have been reported to be similar to that of microbial fuel cells. A general problem with photovoltaic MFC is the $\mathrm{pH}$ membrane gradient which reduces cell voltage and power output. To address this issue, Strik et al developed a PMFC with a reversible bioelectrode responsible for both biocatalyzed anodic and cathodic electron transfer. Anodic produced protons were used for the cathodic reduction reaction which held the formation of a $\mathrm{pH}$ membrane gradient. The microbial fuel cell continuously generated electricity and repeatedly reversed polarity dependent on aeration or solar energy exposure. Identified organisms within biocatalyzing biofilm of the reversible bioelectrode were algae, (cyano) bacteria and protozoa. These results encourage application of solar energy powered microbial fuel cells [97]. To improve the performance of the photo bioreactors, essential steps will include reduction of energy input in pumping; increasing photosynthetic efficiency; improving electron transfer mechanism from algae to the electrochemically active bacteria.

\section{Summary: Mxc Technology towards Practical Applications}

The number of patent applications for MXC technologies has been increasing steadily over the past decade [125]. Figure 6 indicates the rapid advancement of MFC technology in context of design, material and operational aspects of the microbial fuel cells which emphasizes the near- possibility of industrial scale development of these systems. However, the experience with field-scale MXC technologies is still limited. The capacity of a largest size MDC has been reported at a liter scale [45]. Further studies are required to demonstrate the positive net-energy-gain in a large scale MDC. It may be beneficial to combine MDCs with systems that yield hydrogen or harvest other fuel feedstock such as algal biomass. The recent research advances show a definitive promise for MXC technology for the future. For instance, it is interesting to note that the normalized power densities in microbial solar cells are in comparable range to thosein contemporary renewable technologies (e.g. wind and photovoltaic technologies) [109]. The possibility of simultaneous (concurrent) electricity generation and biomass production offers opportunities for the production of

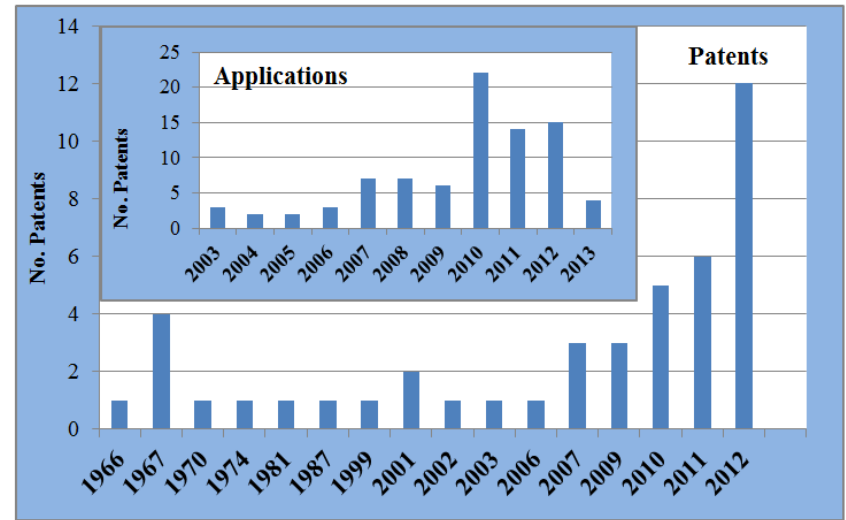

Figure 6: Trends in patent grants and applications for MFC based technologies.

valuable by-products such as biogas or biofuel. The integration of photosynthetic microbial fuel cells with green roofs offers advantages of decentralized bio-electricity production, green roof systems (e.g. storm water retention), thereby increasing aesthetic value, biodiversity, and improving air quality and building insulation. This integrated configuration provides all these new advantages without compromising existing benefits of the green roofs [126]. Overall, the MXC technologies are advancing at stead-fast rates and technological breakthroughs may soonenableMXCs as practical solutions to multitude of environmental problems.

\section{Acknowledgements}

Bahareh Kokabian and Veera Gnaneswar Gude acknowledge the financial support provided by the Office of Research and Economic Development (ORED) Bagley College of Engineering (BCoE), and Department of Civil and Environmental Engineering (CEE) at Mississippi State University.

Dr. Gadhamshetty acknowledges funding support from FGCU Multidisciplinary Research Initiative Award by Office of Research \& Graduate Studies at Florida Gulf Coast University; New York State Pollution Prevention Institute; and Environmental Protection Agency (Grant No. SU835305). The funding source had no involvement in study design; in the collection, analysis and interpretation of data; in the writing of the report; and in the decision to submit the paper for publication.

We thank the anonymous reviewers for their valuable comments.

\section{References}

1. Lee $\mathrm{Y}$, Nirmalakhandan N (2011) Electricity production in membrane-less microbial fuel cell fed with livestock organic solid waste. Bioresour Technol 102: $5831-5835$

2. Feng $Y$, Wang $X$, Logan BE, Lee $H(2008)$ Brewery wastewater treatment using air-cathode microbial fuel cells. Appl Microbiol Biotechnol 78: 873-880.

3. Greenman J, Gálvez A, Giusti L, leropoulos I (2009). Electricity from landfil leachate using microbial fuel cells: Comparison with a biological aerated filter Enzyme and Microbial Technology 44: 112-119.

4. Patil SA, Surakasi VP, Koul S, ljmulwar S, Vivek A, et al. (2009) Electricity generation using chocolate industry wastewater and its treatment in activated sludge based microbial fuel cell and analysis of developed microbial community in the anode chamber. Bioresour Technol 100: 5132-5139.

5. Oh SE, Logan BE (2005) Hydrogen and electricity production from a food processing wastewater using fermentation and microbial fuel cell technologies. Water Res 39: 4673-4682.

6. Borole AP, Hamilton CY (2009). Energy production from food industry wastewaters using bioelectrochemical cells. In: Emerging Environmental Technologies. Springer Publications.

7. He Z, Angenent LT (2006) Application of bacterial biocathodes in microbial fue cells. Electroanalysis 18: 2009-2015. 
Citation: Gude VG, Kokabian B, Gadhamshetty V (2013) Beneficial Bioelectrochemical Systems for Energy, Water, and Biomass Production. J Microb Biochem Technol S6: 005. doi:10.4172/1948-5948.S6-005

Page 12 of 14

8. Butler CS, Clauwaert P, Green SJ, Verstraete W, Nerenberg R (2010) Bioelectrochemical perchlorate reduction in a microbial fuel cell. Environ Sci Technol 44: 4685-4691.

9. Gregory KB, Lovley DR (2005) Remediation and recovery of uranium from contaminated subsurface environments with electrodes. Environ Sci Technol 39: 8943-8947.

10. Li Z, Yang S, Inoue Y, Yoshida N, Katayama A (2010) Complete anaerobic mineralization of pentachlorophenol (PCP) under continuous flow conditions by sequential combination of PCP-dechlorinating and phenol-degrading consortia. Biotechnol Bioeng 107: 775-785.

11. Huang L, Regan JM, Quan X (2011) Electron transfer mechanisms, new applications, and performance of biocathode microbial fuel cells. Bioresour Technol 102: 316-323.

12. Kim Y, Logan BE (2013) Microbial desalination cells for energy production and desalination. Desalination 308: 122-130.

13. Cusick RD, Kim Y, Logan BE (2012) Energy Capture from Thermolytic Solutions in Microbial Reverse-Electrodialysis Cells. Science 335: (6075) 1474-1477.

14. Sasaki K, Morita M, Sasaki D, Hirano S, Matsumoto N et al. (2011). Methanogenic communities on the electrodes of bioelectrochemical reactors without membranes. J Biosci Bioeng 111: 47-49.

15. Tartakovsky B, Manuel M.-F., Wang H, Guiot SR (2009) High rate membraneless microbial electrolysis cell for continuous hydrogen production. International journal of hydrogen energy 34: 672-677.

16. Pisciotta JM, Zou Y, Baskakov IV (2010) Light-Dependent Electrogenic Activity of Cyanobacteria. PLoS ONE 5(5): e10821. doi:10.1371/journal.pone.0010821.

17. Logan BE (2008) Microbial Fuel Cells. John Wiley \& sons, New Jersey.

18. Logan BE (2010) Scaling up microbial fuel cells and other bioelectrochemica systems. Appl Microbiol Biotechnol 85: 1665-1671.

19. Torres CI, Marcus AK, Lee HS, Parameswaran P, Krajmalnik-Brown R, et al. (2010) A kinetic perspective on extracellular electron transfer by anoderespiring bacteria. FEMS Microbiol Rev 34: 3-17.

20. Mohan SV, Srikanth S, Sarma PN (2009) Non-catalyzed microbial fuel cell (MFC) with open air cathode for bioelectricity generation during acidogenic wastewater treatment. Bioelectrochemistry 75: 130-135.

21. Rabaey K, Verstraete W (2005) Microbial fuel cells: novel biotechnology for energy generation. Trends Biotechnol 23: 291-298.

22. Du Z, Li H, Gu T (2007) A state of the art review on microbial fuel cells: A promising technology for wastewater treatment and bioenergy. Biotechnol Adv 25: $464-482$

23. Rishman-Yazdi H, Carver SM, Christy AD, Tuovinen $\mathrm{OH}$ (2008) Cathodic limitations in microbial fuel cells: An overview. Journal of Power Sources 180: 683-694.

24. Pham TH, Rabaey K, Aelterman $P$, Clauwaert $P$, De Schamphelaire $L$ et al (2006) Microbial Fuel Cells in Relation to Conventional Anaerobic Digestion Technology. Eng Life Sci 6: 285-292.

25. Schröder U (2007) Anodic electron transfer mechanisms in microbial fuel cells and their energy efficiency. Phys Chem Chem Phys 9: 2619-2629.

26. Borole AP, Reguera G, Ringeisen B, Wang Z-W, Feng Y, Kim BH (2011) Electroactive biofilms: Current status and future research needs. Energy Environ Sci 4: 4813-4834.

27. Piccolino M (1998) Animal electricity and the birth of electrophysiology: the legacy of Luigi Galvani. Brain Res Bull 46: 381-407.

28. Potter MC (1911) Electrical Effects Accompanying the Decomposition of Organic Compounds. R Soc Lond 84: 260-276.

29. Cohen B (1931) The Bacterial Culture as an Electrical Half-Cell. Journal of Bacteriology 21: 18-19

30. Canfield JH, Goldner BH, Lutwack R (1963) NASA Technical report, Magna Corporation, Anaheim, CA.

31. Bennetto HP, Tanaka K, Matsuda K (1984) Biofuel Cells containing algae: In charge and field effects in biosystems. Life Chem Rep 2: 363.

32. El-Naggar MY, Wanger G, Leung KM, Yuzvinsky TD, Southam G, et al. (2010) Electrical transport along bacterial nanowires from Shewanella oneidensis MR-
1. Proc Natl Acad Sci U S A 107: 18127-18131.

33. El-Naggar MY, Gorby YA, Xia W, Nealson KH (2008) The molecular density of states in bacterial nanowires. Biophys J 95: L10-12.

34. Reguera G, McCarthy KD, Mehta T, Nicoll JS, Tuominen MT, et al. (2005) Extracellular electron transfer via microbial nanowires. Nature 435: 1098-1101.

35. Ramaraja PR, Gadhamshetty V, Nadeau LJ, Johnson G (2009) Impedance spectroscopy as a Tool for Non-Intrusive Detection of Extracellular mediators in microbial fuel cells. Biotechnology \& Bioengineering. 104(5) 882-891

36. Cao XX, Huang X, Liang P, Xiao K, Zhou YJ, Zhang XY, Logan BE, (2009) A new method for water desalination using microbial desalination cells. Environ. Sci. Technol. 43: 7148-7152.

37. Chen X, Xia X, Liang P, Cao X, Sun H, et al. (2011) Stacked microbia desalination cells to enhance water desalination efficiency. Environ Sci Technol 45: $2465-2470$

38. Luo H, Jenkins PE, Ren Z (2011) Concurrent desalination and hydrogen generation using microbial electrolysis and desalination cells. Environ Sci Technol 45: 340-344.

39. Mehanna M, Kiely PD, Call DF, Logan BE (2010) Microbial electrodialysis cell for simultaneous water desalination and hydrogen gas production. Environ Sci Technol 44: 9578-9583.

40. Mehanna M, Saito T, Yan J, Hickner M, Cao X et al. (2011) Using microbia desalination cells to reduce water salinity prior to reverse osmosis. Energy Environ Sci 3: 1114-1120.

41. Qu Y, Feng Y, Wang X, Liu J, Lv J, et al. (2012) Simultaneous water desalination and electricity generation in a microbial desalination cell with electrolyte recirculation for $\mathrm{pH}$ control. Bioresour Technol 106: 89-94.

42. Luo H, Xu P, Roane TM, Jenkins PE, Ren Z (2012) Microbial desalination cells for improved performance in wastewater treatment, electricity production, and desalination. Bioresour. Technol. 105: 60-66.

43. Kim Y, Logan BE (2011) Series assembly of microbial desalination cells containing stacked electrodialysis cells for partial or complete seawater desalination. Environ. Sci. Technol. 45: 5840-5845.

44. Zhang B, He Z (2012) Integrated salinity reduction and water recovery in an osmotic microbial desalination cell. RSC Adv 2: 3265-3269.

45. Jacobson KS, Drew DM, He Z (2011) Use of a liter-scale microbial desalination cell as a platform to study bioelectrochemical desalination with salt solution or artificial seawater. Environ. Sci. Technol. 45: 4652-4657.

46. Jacobson KS, Drew DM, He Z (2011) Efficient salt removal in a continuously operated upflow microbial desalination cell with an air cathode. Bioresour. Technol. 102: 376-380.

47. Schroder, Harnisch F, Schröder U (2010) From MFC to MXC: chemica and biological cathodes and their potential for microbial bioelectrochemical systems. Chem. Soc. Rev 39: 4433-4448.

48. Lee HS, Parameswaran P, Kato-Marcus A, Torres Cl, Rittmann BE (2008) Evaluation of energy-conversion efficiencies in microbial fuel cells (MFCs) utilizing fermentable and non-fermentable substrates. Water Res 42: 1501 1510.

49. Biffinger JC, Pietron J, Ray R, Little B, Ringeisen BR (2007) A biofilm enhanced miniature microbial fuel cell using Shewanella oneidensis DSP10 and oxygen reduction cathodes. Biosens Bioelectron 22: 1672-1679.

50. Freguia S, Rabaey K, Yuan Z, Keller J (2008) Sequential anode-cathode configuration improves cathodic oxygen reduction and effluent quality of microbial fuel cells. Water Research 42:1387-1396

51. Sun $Y$, Wei J, Liang $P$, Huang $X$ (2012) Microbial community analysis in biocathode microbial fuel cells packed with different materials. AMB Express 2: 21

52. Clauwaert P, Van der Ha D, Boon N, Verbeken K, Verhaege M, et al. (2007) Open air biocathode enables effective electricity generation with microbial fue cells. Environ Sci Technol 41: 7564-7569.

53. Sharma V, Kundu PP (2010) Biocatalysts in microbial fuel cells. Enzyme and Microbial Technology 47: 179-188.

54. Clauwaert P, Rabaey K, Aelterman P, de Schamphelaire L, Pham TH, et al. 
Citation: Gude VG, Kokabian B, Gadhamshetty V (2013) Beneficial Bioelectrochemical Systems for Energy, Water, and Biomass Production. J Microb Biochem Technol S6: 005. doi:10.4172/1948-5948.S6-005

(2007) Biological denitrification in microbial fuel cells. Environ Sci Technol 41 : 3354-3360.

55. Zhang G, Zhao Q, Jiao Y, Wang K, Lee DJ, et al. (2012) Biocathode microbial fuel cell for efficient electricity recovery from dairy manure. Biosens Bioelectron 31: $537-543$

56. Rozendal RA, Jeremiasse AW, Hamelers HV, Buisman CJ (2008) Hydrogen production with a microbial biocathode. Environ Sci Technol. 42: 629-34.

57. Pisciotta JM, Zaybak Z, Call DF, Nam JY, Logan BE (2012) Enrichment of Microbial Electrolysis Cell Biocathodes from Sediment Microbial Fuel Cell Bioanodes. Appl Environ Microbiol. 78: 5212-5219.

58. Cheng KY, Ho G, Cord-Ruwisch R (2011) Novel methanogenic rotatable bioelectrochemical system operated with polarity inversion. Environ Sci Technol 45: 796-802.

59. Cheng S, Xing D, Call DF, Logan BE (2009) Direct biological conversion of electrical current into methane by electromethanogenesis. Environ Sci Technol 43: 3953-3958.

60. Strycharz SM, Gannon SM, Boles AR, Franks AE, Nevin KP, et al. (2010) Reductive dechlorination of 2-chlorophenol by Anaeromyxobacter dehalogenans with an electrode serving as the electron donor. Environ Microbiol Rep 2: 289-294

61. Gadhamshetty V, Koratkar N (2012) Nano-Engineered Biocatalyst-Electrode Structures for Next Generation Microbial Fuel Cells. Nano Energy 1: 3-5

62. Upadhyayula VK, Gadhamshetty V (2010) Appreciating the role of carbon nanotube composites in preventing biofouling and promoting biofilms on material surfaces in environmental engineering: a review. Biotechnol Adv 28 802-816

63. Xiao L, Damien J, Luo J, Jang HD, Huang J, et al. (2012) Crumpled graphene particles for microbial fuel cell electrodes. Journal of Power Sources 208: 187192.

64. Krishnamoorthy A, Gadhamshetty V, Koratkar N (2013) Passivation of microbial corrosion using graphene coating, Carbon (In Press).

65. Dumas C, Mollica A, Féron D, Basseguy R, Etcheverry L, et al. (2008) Checking graphite and stainless anodes with an experimental model of marine microbial fuel cell. Bioresour Technol 99: 8887-8894.

66. Erable B, Bergel A (2009) First air-tolerant effective stainless steel microbia anode obtained from a natural marine biofilm. Bioresour Technol 100: 3302 3307.

67. Heijne A, Hamelers HVM, Saakes M, Buisman CJN (2008) Performance of non-porous graphite and titanium-based anodes in microbial fuel cells. Electrochimica Acta 53: 5697-5703.

68. Fan Y, Xu S, Schaller R, Jiao J, Chaplen F, et al. (2011) Nanoparticle decorated anodes for enhanced current generation in microbial electrochemical cells. Biosens Bioelectron 26: 1908-1912.

69. Liu X, Du X, Wang X, Li N, Xu P, et al. (2013) Improved microbial fuel cell performance by encapsulating microbial cells with a nickel-coated sponge. Biosens Bioelectron 41: 848-851.

70. Chen S, Liu G, Zhang R, Qin B, Luo Y (2012) Development of the microbial electrolysis desalination and chemical-production cell for desalination as well as acid and alkali productions. Environ Sci Technol 46: 2467-2472.

71. Forrestal C, Xu P, Jenkins PE, Ren Z (2012) Microbial desalination cell with capacitive adsorption for ion migration control. Bioresour Technol 120: 332-

72. Morel A, Zuo K, Xia X, Wei J, Luo X, et al. (2012) Microbial desalination cells packed with ion-exchange resin to enhance water desalination rate. Bioresour Technol 118: 43-48.

73. Luo H, Xu P, Jenkins PE, Ren Z (2012) lonic composition and transport mechanisms in microbial desalination cells. Journal of Membrane Science 409- 410: 16- 23

74. Davis RJ, Kim Y, Logan BE. (2013) Increasing Desalination by Mitigating Anolyte $\mathrm{pH}$ Imbalance Using Catholyte Effluent Addition in a Multi-Anode Bench Scale Microbial Desalination Cell. Sustainable Chemistry \& Engineering.

75. Sleutels TH, Hamelers HV, Buisman CJ (2010) Reduction of pH buffer requirement in bioelectrochemical systems. Environ Sci Technol 44: 82598263.
76. Gude VG (2012) Algal-microbial desalination cells for clean energy, water and biomass production. proceedings of National Environmental Monitoring Conference, August 5-10, Washington DC, 2012

77. Kokabian B, Gude VG (2013) Algae cathode chamber for enhanced performance in microbial desalination cells. Proceedings of Second International symposium on bioremediation and sustainable environmental technologies, Jacksonville FL.

78. Wang X, Feng Y, Liu J, Lee H, Li C, et al. (2010) Sequestration of CO2 discharged from anode by algal cathode in microbial carbon capture cells (MCCs). Biosens Bioelectron 25: 2639-2643.36

79. Lundquist TJ (2010) Production of Algae in Conjunction with Wastewate Treatment. Civil and Environmental Engineering Department, California Polytechnic State University, San Luis Obispo.

80. De Schamphelaire L, Verstraete W (2009) Revival of the biological sunlight-tobiogas energy conversion system. Biotechnol Bioeng 103: 296-304

81. Zhang Y, Angelidaki I (2013) A new method for in situ nitrate removal from groundwater using submerged microbial desalination-denitrification cell (SMDDC). Water Res 47: 1827-1836.

82. Brastad KS, He Z (2013) Water softening using microbial desalination cell technology. Desalination 309: 32-37.

83. McCarty PL, Bae J, Kim J (2011) Domestic wastewater treatment as a ne energy producer--can this be achieved? Environ Sci Technol 45: 7100-7106.

84. Lardon L, Hélias A, Sialve B, Steyer JP, Bernard O (2009) Life-cycle assessment of biodiesel production from microalgae. Environ Sci Technol 43: 6475-6481.

85. Spiegler KS (1966) Desalination Research and Water Resources. In: Principles of Desalination, Academic Press.

86. Gude VG (2011) Energy consumption and recovery in reverse osmosis. Desalination and water treatment 36: 239-260.

87. Gude VG, Nirmalakhandan N, Deng S (2010) Renewable and sustainable approaches for desalination. Renewable and Sustainable Energy Reviews 14 2641-2654

88. Subramani A, Badruzzaman M, Oppenheimer J, Jacangelo JG (2011) Energy minimization strategies and renewable energy utilization for desalination: a review. Water Res 45: 1907-1920.

89. Kim Y, Logan BE (2011) Hydrogen production from inexhaustible supplies of fresh and salt water using microbial reverse-electrodialysis electrolysis cells. Proc Natl Acad Sci U S A 108: 16176-16181.

90. He Z, Kan J, Mansfeld F, Angenent LT, Nealson KH (2009) Self-sustained phototrophic microbial fuel cells based on the synergistic cooperation between photosynthetic microorganisms and heterotrophic bacteria. Environ. Sci. Technol.43: 1648-1654

91. Powell EE, Mapiour ML, Evitts RW, Hill GA (2009) Growth Kinetics of Chlorella vulgaris and Its Use as a Cathodic Half Cell. Bioresource Technol. 100: 269274

92. Powell EE, Bolster J., Hill GA, Evitts RW (2011) Microbial Fuel Cell With a Photosynthetic Microalgae Cathodic Half Cell Coupled to a Yeast Anodic Half Cell. Energy Sources A 33: 440-448.

93. Mitra P, Hill GA (2012) Continuous Microbial Fuel Cell Using a Photoautotrophic Cathode and a Fermentative Anode. Can. J. Chem. Eng. 90: 1006-1010

94. Velasquez-Orta S, Curtis T, Logan BE (2009) Energy From Algae Using Microbial Fuel Cells, Biotechnol. Bioeng. 103:1068-1076.

95. Gadhamshetty V, Belanger D, Gardiner CJ, Cummings A, Hynes A (2013) Evaluation of Laminaria-based microbial fuel cells (LbMs) for electricity production. Bioresource Technology 127:378-385

96. Strik DP, Hamelers HV, Buisman CJ (2010) Solar energy powered microbia fuel cell with a reversible bioelectrode. Environ Sci Technol 44: 532-537.

97. Strik DPBTB, Hamelers HVM, Buisman CJN (2010) Solar Energy Powered Microbial Fuel Cell with a Reversible Bioelectrode. Environ. Sci. Technol. 44 532-537.

98. Malik S, Drott E, Grisdela P, Lee J, Lee C et al. (2009) A self assembling self-repairing microbial photoelectrochemical solar cell. Energy Environ. Sci. 2: 292-298.

99. Cao X.X, Huang X, Liang P, Boon N, Fan MZ et al. (2009) A completely 
Citation: Gude VG, Kokabian B, Gadhamshetty V (2013) Beneficial Bioelectrochemical Systems for Energy, Water, and Biomass Production. J Microb Biochem Technol S6: 005. doi:10.4172/1948-5948.S6-005

Page 14 of 14

anoxic microbial fuel cell using a photo-biocathode for cathodic carbon dioxide reduction. Energy Environ. Sci. 2: 498-501.

100. Zou Y, Pisciotta J, Billmyre RB, Baskakov IV (2009) Photosynthetic microbia fuel cells with positive light response. Biotechnol Bioeng 104: 939-946.

101. Zou Y, Pisciotta J, Baskakov IV (2010) Nanostructured polypyrrole-coated anode for sun-powered microbial fuel cells. Bioelectrochemistry 79: 50-56.

102. Thorne R (2011) Bio-Photo-Voltaic Cells (Photosynthetic - Microbial Fuel Cells). PhD Dissertation, University of Bath, Bath, UK.

103. Lam KB, Johnson EA, Chiao M, Lin LW (2006) A MEMS photosynthetic electrochemical cell powered by subcellular plant photosystems. Journal of Microelectromechanical Systems 15: 1243-1250.

104. Maly J, Masojidek J, Masci A, llie M, Cianci E, et al. (2005) Direct mediatorless electron transport between the monolayer of photosystem II and poly(mercapto-p-benzoquinone) modified gold electrode--new design of biosensor for herbicide detection. Biosens Bioelectron 21: 923-932.

105. Badura A, Esper B, Ataka K, Grunwald C, Wöll C, et al. (2006) Light-driven water splitting for (bio-)hydrogen production: photosystem 2 as the central part of a bioelectrochemical device. Photochem Photobiol 82: 1385-1390.

106. Janzen AF, Seibert M (1980) Photoelectrochemical conversion using reactioncenter electrodes. Nature 286: 584-585

107. Amao Y, Komori T (2004) Bio-photovoltaic conversion device using chlorine-e6 derived from chlorophyll from Spirulina adsorbed on a nanocrystalline $\mathrm{TiO} 2$ film electrode. Biosens Bioelectron 19: 843-847.

108. Malik S, Drott E, Grisdela P, Lee J, Lee C, Lowy DA, Gray S, Tender LM (2009) A self-assembling self-repairing microbial photoelectrochemical solar cell. Energy Environ. Sci. 2: 292-298.

109. Strik DPBTB, Timmers RA, Helder M, Steinbusch KJJ, Hamelers HVM Buisman CJN (2011) Microbial solar cells: Applying photosynthetic and electrochemically active organisms. Trends Biotechnol 29(1):41-49 (2011).

110. De Schamphelaire L, Van den Bossche L, Dang HS, Höfte M, Boon N, et al. (2008) Microbial fuel cells generating electricity from rhizodeposits of rice plants. Environ Sci Technol 42: 3053-3058

111. Kaku N, Yonezawa N, Kodama Y, Watanabe K (2008) Plant/microbe cooperation for electricity generation in a rice paddy field. Appl Microbio Biotechnol 79: 43-49.

112. Lynch JM, Whipps JM (1990) Substrate flow in the rhizosphere. Plant Soil 129: 1-10.

113. Helder M, Strik DP, Hamelers HV, Kuhn AJ, Blok C, et al. (2010) Concurrent bio-electricity and biomass production in three Plant-Microbial Fuel Cells using Spartina anglica, Arundinella anomala and Arundo donax. Bioresour Technol 101: 3541-3547.

114. Ryu W, Bai SJ, Park JS, Huang Z, Moseley J, et al. (2010) Direct extraction of photosynthetic electrons from single algal cells by nanoprobing system. Nano Lett 10: 1137-1143.

115. Yagishita T, Sawayama S, Tsukahara K, Ogi T (1999) Effects of glucose addition and light on current outputs in photosynthetic electrochemical cells using Synechocystis sp. PCC6714. J Biosci Bioeng 88: 210-214.

116. Chiao M, Lam KB, and Lin LW (2006) Micromachined microbial and photosynthetic fuel cells. J Micromech Microeng 16: 2547-2553.

117. Yagishita T, Sawayama S, Tsukahara KI, Ogi T (1997) Effects of intensity of incident light and concentrations ofSynechococcus sp. and 2-hydroxy-1,4naphthoquinone on the current output of photosynthetic electrochemical cell. Sol Energy 61: 347-353.

118. Rosenbaum M, Schröder U, Scholz F (2005) Utilizing the green alga Chlamydomonas reinhardtii for microbial electricity generation: a living solar cell. Appl Microbiol Biotechnol 68: 753-756.

119. Melis A, Zhang L, Forestier M, Ghirardi ML, Seibert M (2000) Sustained photobiological hydrogen gas production upon reversible inactivation of oxygen evolution in the green alga Chlamydomonas reinhardtii. Plant Physiol 122: $127-136$

120. Berk RS, Canfield JH (1964) BIOELECTROCHEMICAL ENERGY CONVERSION. Appl Microbiol 12: 10-12.

121. Croft MT, Lawrence AD, Raux-Deery E, Warren MJ, Smith AG (2005) Algae acquire vitamin B12 through a symbiotic relationship with bacteria. Nature 438: $90-93$

122. Strik DP, Terlouw H, Hamelers HV, Buisman CJ (2008) Renewable sustainable biocatalyzed electricity production in a photosynthetic algal microbial fuel cell (PAMFC). Appl Microbiol Biotechnol 81: 659-668.

123. Jiang H, Luo S, Shi X, Dai M, Guo RB (2012) A novel microbial fuel cell and photobioreactor system for continuous domestic wastewater treatment and bioelectricity generation. Biotechnol Lett 34: 1269-1274.

124. Jiang H, Luo S, Shi X, Dai M, Guo RB (2013) A system combining microbia fuel cell with photobioreactor for continuous domestic wastewater treatment and bioelectricity generation. J Cent South Univ.20: 488-494.

125. Biffinger JC, Ringeisen BR (2008) Engineering microbial fuels cells: recent patents and new directions. Recent Pat Biotechnol 2: 150-155.

126. Helder M, Chen W-S, Van der Harst EJM, Strik DPBTB, Hamelers HVM et al. (2013) Electricity production with living plants on a green roof: environmental performance of the plant-microbial fuel cell. Biofuels Bioprod Bioref 7: 52-64.

127. Wen Q, Zhang H, Chen Z, Li Y, Nan J, et al. (2012) Using bacterial catalyst in the cathode of microbial desalination cell to improve wastewater treatment and desalination. Bioresour Technol 125: 108-113.

128. Qu Y, Feng Y, Liu J, He W, Shi X, Yang Q, Lv J, Logan BE (2013) Salt removal using multiple microbial desalination cells under continuous flow conditions. Desalination 317: 17-22.

129.Zhang F, Chen M, Zhang Y, Zeng RJ (2012) Microbial desalination cells with ion exchange resin packed to enhance desalination at low salt concentration. Journal of Membrane Science 417-418: 28-33.

130. Bo Z, He Z (2013) Improving water desalination by hydraulically coupling an osmotic microbial fuel cell with a microbial desalination cell. Journal of Membrane science 441: 18-24

131.Zhang B, He Z (2012) Energy production, use and saving in a bioelectrochemical desalination system. RSC Advances 2: 10673-10679.

132. Juang DF, Yang PC, Kuo TH (2012) Effects of flow rate and chemical oxygen demand removal characteristics on power generation performance of microbial fuel cells. Int J Environ. Sci Technol 9: 267-280

133. Zhang Y, Noori JS, Angelidaki I (2011) Simultaneous organic carbon, nutrients removal and energy production in a photomicrobial fuel cell (PFC). Energy Environ Sci 4: 4340-4346.

134. Pandit S, Nayak BK, Das D (2012) Microbial carbon capture cell using cyanobacteria for simultaneous power generation, carbon dioxide sequestration and wastewater treatment. Bioresour Technol 107: 97-102.

135. Zhou M, He H, Jin T, Wang $\mathrm{H}$ (2012) Power generation enhancement in nove microbial carbon capture cells with immobilized Chlorella vulgaris. Journal of Power Sources 214: 216-219.

This article was originally published in a special issue, Biofuel Cells and Bioelectrochemical systems handled by Editor(s). Abhijeet P Borole, Oak Ridge National Laboratory, USA; Justin C Biffinger, US Naval Research Laboratory, USA 